\title{
28. NEUTRON ACTIVATION ANALYSIS OF RARE EARTH ELEMENTS AND SOME OTHER TRACE ELEMENTS IN VOLCANIC ASHES AND PELAGIC CLAYS, DEEP SEA DRILLING PROJECT LEG 59
}

\author{
A. A. Migdisov, A. Z. Miklishansky, B. V. Saveliev, N. V. Bredanova, Yu. P. Girin, \\ V. I. Pavlutskaya, and Y. V. Yakovlev, V. I. Vernadsky Institute of Geochemistry and Analytical Chemistry, \\ U.S.S.R. Academy of Sciences, Moscow 117334, U.S.S.R.
}

\section{INTRODUCTION}

Published data on trace- and dispersed-element distributions, including rare-earth elements (REE), in volcanic rocks of the Mariana island-arc system are very limited (Taylor, 1968) and are virtually unavailable for sediments. Thus determinations of trace-element abundances in the volcanic and sedimentary rocks penetrated by drilling during DSDP Leg 59 is of significant interest.

Rock samples from the sedimentary sequence in the southern part of the Philippine Sea were obtained from six holes at five drill sites (the West Philippine Basin, the Palau-Kyushu Ridge, the Parece Vela Basin, and the West Mariana Ridge). The sequence is represented by vitric tuffs, volcaniclastic breccias, carbonate sediments, and pelagic clays, which vary in age from middle Oligocene to Pleistocene.

The samples examined in this study have provided an opportunity to investigate three questions:

1) What trace-element distribution patterns can be identified in products of explosive volcanism at various formation stages of the Mariana island-arc system?

2) How can we evaluate trace-element distributions in seawater-pyroclastic debris interactions that have varied in time in the Philippine Sea?

3) What possible occurrences of metalliferous basal sediments in the basins are analogous to the metalliferous deposits characteristic of the rift zones of intense oceanic and continental volcanism (Boström, 1973; Degens and Ross, 1969; Bonatti et al., 1972; Bonatti, Zerbi et al., 1976; Cronan, 1976; Zelenov, 1964; Strakhov, 1976; Lisitsin et al., 1976; Migdisov et al., 1979)?

The first two questions can be solved on the basis of the available core samples, because the tuffs represent both the sedimentary apron of an older (the PalauKyushu Ridge) remnant arc and that of a younger (the West Mariana Ridge) remnant arc.

According to modern tectonic models (Karig, 1971), the formation of the inter-arc basins occurred under conditions of spreading that justify investigation of the third question. Also, evaluation of metalliferous deposits in terms of trace-element distribution in Holes 447A and 449 of Leg 59 is of interest.

\section{EXPERIMENTAL TECHNIQUES}

Prepowdered samples were washed to remove marine salts before analysis. Radiochemical and instrumental neutron activation analysis
(INAA) methods were used to determine the contents of trace elements. The 5 to $15 \mathrm{mg}$ samples and $\mathrm{W}-1, \mathrm{BCR}-1, \mathrm{BM}$, GSP-1, G-1, $\mathrm{TB}$, and $\mathrm{KH}$ standard rocks (Flanagan, 1973) were put in quartz crucibles to be irradiated at $1.2 \times 10^{13} \mathrm{n} \mathrm{cm}^{-2} \mathrm{~s}^{-1}$ for 20 hours. In INAA, the samples were allowed to cool for 7 to 10 days; gamma-ray radioactivity was measured using a $40-\mathrm{cm}^{3} \mathrm{Ge}(\mathrm{Li})$ detector and a TRIDAK 4000 channel amplitude analyzer controlled by a computer to process the gamma-ray spectra.

In the radiochemical neutron activation analysis (RNAA), the samples were dissolved after irradiation in concentrated HF and $\mathrm{HNO}_{3}$ with 1 to $2 \mathrm{mg}$ of $\mathrm{La}$ carrier. Evaporation was performed to remove $\mathrm{SiF}_{4}$. Precipitation of REE fluorides followed. The fluoride precipitate was dissolved through heating in a $\mathrm{H}_{3} \mathrm{BO}_{3}+0.5 \mathrm{~N} \mathrm{HNO}_{3}$ solution, and REE oxalates were precipitated. The same procedure was employed to treat a sample of the BCR-1 standard.

In addition, REE oxide separation for 12 tuff and sedimentary samples and for a BM standard sample was duplicated using the method of Varshal and Riabchikov (1964).

Samples weighing $2 \mathrm{~g}$ were acidified to disintegration with a $\mathrm{HClO}$ and $\mathrm{HF}$ mixture. Excess $\mathrm{NH}_{4} \mathrm{OH}$, devoid of $\mathrm{CO}_{2}$, was used to precipitate REE chlorides as hydroxides.

The hydroxides obtained were heated and chloridized in a quartz tube furnace at 500 to $600^{\circ} \mathrm{C}$. After dissolution of the oxides in $\mathrm{HCl}$, REE hydroxides were precipitated to remove $\mathrm{Ca}$. The hydroxide precipitate was treated with oxalic acid to obtain REE oxalates. The solution aliquot containing the REE oxalates was collected for the INAA (duplicated by the analysis of REE standard samples). The remaining solution was used to determine $\mathrm{Yt}$ and light lanthanides $\mathrm{La}$, $\mathrm{Ce}, \mathrm{Pr}, \mathrm{Nd}$, and $\mathrm{Sm}$ by distributive paper chromatography (Gelman et al., 1963). Thus four duplicating methods of REE determination were used in the study.

\section{RESULTS}

The analytical results for the geochemical reference samples are presented in Table 1.

The REE abundances for 17 core samples derived from Leg 59 are given in Tables 2 through 5 . The abundance of 6 to 12 REE were determined to evaluate their distribution patterns in the volcanic and sedimentary rocks in the upper sections of Holes $447 \mathrm{~A}$ to 451 . The distributions of $\mathrm{Ce}, \mathrm{Eu}, \mathrm{Tb}, \mathrm{Lu}, \mathrm{Th}, \mathrm{Hf}, \mathrm{Sc}$, and $\mathrm{Sb}$ as obtained by INAA are shown in Tables 6 through 10 .

\section{TRACE ELEMENTS IN TUFFS}

Tables 2 through 10 show REE distribution values for 18 samples of well-bedded or thick, massive vitric tuffs in three out of the five sites. The rocks characterize the middle upper Oligocene sedimentary apron in the West Philippine Basin (Site 447) that appears to be related to the Palau-Kyushu remnant arc, the volcaniclastic debris of the Palau-Kyushu Ridge itself (Site 448 ), the analogous apron of the younger West Mariana 


\section{A. A. MIGDISOV ET AL.}

Table 1. REE distributions for the geochemical reference samples ${ }^{\mathrm{a}}(\mathrm{ppm})$.

\begin{tabular}{|c|c|c|c|c|c|c|c|c|}
\hline \multirow{2}{*}{$\begin{array}{l}\text { Standard } \\
\text { Samples }\end{array}$} & \multicolumn{5}{|c|}{ Nondestructible INAA } & \multirow{2}{*}{$\frac{\text { RNAA }}{\text { BCR-1 }}$} & \multirow{2}{*}{$\begin{array}{c}\begin{array}{c}\text { Total REE INAA } \\
\text { (solution) }\end{array} \\
\text { BM }\end{array}$} & \multirow{2}{*}{$\begin{array}{c}\begin{array}{c}\text { Paper } \\
\text { Chromatography }\end{array} \\
\text { BM }\end{array}$} \\
\hline & G-1 & W-1 & TB & $\mathrm{KH}$ & $\mathrm{BM}$ & & & \\
\hline \multicolumn{9}{|l|}{ Element } \\
\hline \multirow{2}{*}{$\mathrm{La}$} & 93 & 10.8 & 47 & 12 & - & 24 & 8 & 9 \\
\hline & $\overline{101}$ & $\overline{9.8}$ & $\overline{56(49)}$ & $\overline{15}$ & & $\overline{26}$ & $\overline{8.6}$ & $\overline{8.6}$ \\
\hline \multirow{2}{*}{$\mathrm{Ce}$} & 160 & & 114 & 17 & 29 & 42 & 22.5 & 20 \\
\hline & $\overline{170}$ & & $\overline{113(101)}$ & $\overline{19}$ & 23 & $\overline{54}$ & 23 & $\overline{23}$ \\
\hline \multirow[t]{2}{*}{$\mathrm{Pr}$} & - & & - & - & - & & - & 2 \\
\hline & & & & & & & & 3.5 \\
\hline \multirow{2}{*}{$\mathrm{Nd}$} & 66.4 & & - & 11 & - & & 17.5 & 14 \\
\hline & $\overline{56}$ & & & $\overline{15}$ & & & $\overline{16}$ & $\overline{16}$ \\
\hline \multirow{2}{*}{$\mathrm{Sm}$} & 6.9 & 3.3 & 7.0 & 2.5 & - & 5.7 & 3.2 & 3.7 \\
\hline & $\overline{8.3}$ & $\overline{3.6}$ & $\overline{9(9.3)}$ & $\overline{2.5}$ & & $\overline{6.6}$ & 4 & 4 \\
\hline \multirow[t]{2}{*}{ Eu } & 0.26 & 1.21 & 1.4 & & 1.15 & 1.6 & 1.25 & - \\
\hline & $\overline{0.19}$ & $\overline{1.11}$ & $1.6(1.7)$ & & $\overline{1.1}$ & $\overline{1.9}$ & $\overline{1.1}$ & \\
\hline$\underline{\mathrm{Gd}}$ & - & - & - & - & - & - & - & - \\
\hline \multirow{2}{*}{$\mathrm{Tb}$} & - & 0.64 & 2.36 & 0.45 & $\underline{0.62}$ & 0.94 & $\underline{1.13}$ & - \\
\hline & - & $\overline{0.65}$ & 2 & $\overline{-}$ & 1 & $\overline{1.0}$ & 1 & \\
\hline Dy & & & - & - & & & - & - \\
\hline \multirow[t]{2}{*}{ Ho } & & & - & - & & 1.0 & - & - \\
\hline & & & - & 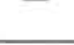 & & $\overline{1.2}$ & & \\
\hline \multirow{2}{*}{ Er } & & & - & - & & 4.2 & - & - \\
\hline & & & & - & & $\overline{3.6}$ & & \\
\hline \multirow{2}{*}{$\mathrm{Yb}$} & $\underline{0.88}$ & 1.8 & 4.2 & 1.1 & 4.4 & 3.28 & 3.1 & - \\
\hline & $\overline{1.05}$ & $\overline{2.1}$ & $\overline{4}$ & $\overline{1}$ & $\overline{3.5}$ & $\overline{3.36}$ & $\overline{3.5}$ & - \\
\hline \multirow{2}{*}{$\mathrm{Lu}$} & 0.18 & 0.36 & 0.48 & 0.16 & & 0.47 & & - \\
\hline & $\overline{0.19}$ & $\overline{0.35}$ & $\overline{0.55}$ & $\overline{0.1}$ & & 0.55 & & \\
\hline \multirow[t]{2}{*}{$\mathrm{Y}$} & & & & & & & & 29 \\
\hline & & & & & & & & $\overline{26}$ \\
\hline
\end{tabular}

a Numerator shows results obtained by each method; denominator shows Flanagan's reference values (1973). Randle's reference values (1974) are given in parentheses.

Table 2. REE distribution (ppm) in samples from Hole 447A.

\begin{tabular}{|c|c|c|c|c|c|c|c|c|c|c|c|c|c|c|c|}
\hline \multirow[b]{3}{*}{ Element } & \multicolumn{4}{|c|}{$\mathrm{N} 26^{\mathrm{a}}$} & \multicolumn{4}{|c|}{ N 28} & \multicolumn{4}{|c|}{ N 32} & \multicolumn{3}{|c|}{ N 33} \\
\hline & \multicolumn{4}{|c|}{$447 \mathrm{~A}-4-3,132-140 \mathrm{~cm}^{\mathrm{b}}$} & \multicolumn{4}{|c|}{$447 \mathrm{~A}-5-5,54-56 \mathrm{~cm}$} & \multicolumn{4}{|c|}{$447 \mathrm{~A} 10-1,34-38 \mathrm{~cm}$} & \multicolumn{3}{|c|}{$447 \mathrm{Al1}-1,11-15 \mathrm{~cm}$} \\
\hline & $\begin{array}{c}\text { INAA } \\
\text { (dry test) }\end{array}$ & $\underset{\text { (solution) }}{\text { INAA }}$ & Chromatography & Average & $\begin{array}{c}\text { INAA } \\
\text { (dry test) }\end{array}$ & $\underset{\text { (solution) }}{\text { INAA }}$ & Chromatography & Average & RNAA & $\begin{array}{c}\text { INAA } \\
\text { (solution) }\end{array}$ & Chromatography & Average & $\begin{array}{l}\text { INAA } \\
\text { (dry test) }\end{array}$ & $\begin{array}{c}\text { INAA } \\
\text { (solution) }\end{array}$ & Average \\
\hline La & 61.1 & e & 69.3 & 65.4 & 18.2 & 18.4 & 19 & 18.5 & 16.4 & 15.4 & 15 & 15.6 & 13.0 & - & 13.0 \\
\hline $\mathrm{Ce}$ & 96.4 & 96 & 96.5 & 96.3 & 32.0 & 32.9 & 35 & 33.3 & 38.0 & 39.2 & 37 & 38.0 & 31.6 & 32.0 & 31.8 \\
\hline $\mathrm{Pr}$ & - & - & 14.9 & 14.9 & - & - & 5.5 & 5.5 & - & - & 5.1 & 5.1 & - & - & - \\
\hline $\mathrm{Nd}$ & 90.3 & 69.1 & 83 & 80.8 & - & 21.9 & 24.0 & 23.0 & 30.6 & 29.7 & 31.0 & 30.5 & - & 27.3 & 27.3 \\
\hline Sm & 13.1 & - & - & 13.1 & 4.5 & 4.8 & - & 4.65 & 5.4 & 6.6 & - & 3.7 & 3.85 & 4.05 & 3.95 \\
\hline Eu & 3.89 & 3.98 & - & 3.94 & 1.2 & 1.42 & - & 1.31 & 1.85 & 1.93 & - & 1.89 & 1.04 & 1.17 & 1.1 \\
\hline Gd & - & - & - & - & - & - & - & - & 6.1 & - & - & 6.1 & - & - & - \\
\hline $\mathrm{Tb}$ & 3.68 & 3.43 & - & 3.56 & - & 1.27 & - & 1.27 & 1.56 & 1.50 & - & 1.53 & 1.0 & 0.99 & 1.0 \\
\hline Ho & - & - & - & - & - & - & - & - & 1.19 & - & - & - & - & - & - \\
\hline Er & - & - & - & - & $=$ & $=$ & - & - & 3.4 & - & - & - & - & - & - \\
\hline $\mathrm{Yb}$ & 7.21 & 7.92 & - & 7.56 & 2.88 & 2.86 & 2.90 & 2.88 & 3.80 & 3.97 & - & 3.88 & 2.92 & 4.16 & 3.54 \\
\hline Lu & 1.06 & 1.22 & - & 1.09 & 0.589 & 0.537 & - & 0.563 & 0.50 & 0.46 & - & 0.48 & 0.441 & 0.502 & 0.472 \\
\hline Y & - & - & 97.5 & - & - & - & 35 & - & - & - & 41.5 & - & - & - & 37.0 \\
\hline
\end{tabular}

a Authors' sample designations used in the text.

bSDP sample numbering system-hole-core-section, interval in $\mathrm{cm}$ (used in Tables 3-5 and following tables as well).

${ }^{c}-$ signifies that the quantity was not determined.

remnant arc in the Parece Vela Basin (Site 450) (Karig, 1971), and the volcaniclastic debris of the West Mariana Ridge itself (Hole 451). Distinguishable vitric tuffs on the western sedimentary apron of the Palau-Kyushu Ridge within the West Philippine Basin (Site 447) are not identified, but Unit 4 may be an altered tuff (Site 447 report, this volume). Also a sedimentary volcani- clastic breccia containing large clasts of altered basalt is found at Hole 447A. East of the Palau-Kyushu Ridge in the western part of the Parece Vela Basin (Site 449), volcaniclastic material is found disseminated in pelagic clays from the middle portion of the sedimentary column. However, distinct layers of tuffs, as postulated by the tectonic models (Karig, 1971), are absent here. 
Table 3. REE distribution (ppm) in samples from Hole 448.

\begin{tabular}{|c|c|c|c|c|c|c|c|c|c|c|}
\hline \multirow[b]{3}{*}{ Element } & \multicolumn{4}{|c|}{ N 36} & \multicolumn{4}{|c|}{ N 45} & \multirow{3}{*}{ 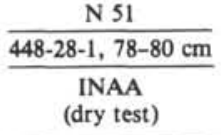 } & \multirow{3}{*}{$\frac{\mathrm{N} 47}{448-21-3,1-4 \mathrm{~cm}}$} \\
\hline & \multicolumn{4}{|c|}{$448-11-1,47-49 \mathrm{~cm}$} & \multicolumn{4}{|c|}{$448-17-5,22-24 \mathrm{~cm}$} & & \\
\hline & $\begin{array}{c}\text { INAA } \\
\text { (dry test) }\end{array}$ & $\begin{array}{c}\text { INAA } \\
\text { (solution) }\end{array}$ & Chromatography & Average & $\begin{array}{c}\text { INAA } \\
\text { (dry test) }\end{array}$ & $\begin{array}{c}\text { INAA } \\
\text { (solution) }\end{array}$ & Chromatography & Average & & \\
\hline La & 8.5 & 9.4 & 9.2 & 9.0 & 6.0 & 6.5 & 5.6 & 6.0 & 4.4 & - \\
\hline $\mathrm{Ce}$ & - & 6.4 & - & 6.4 & 15.7 & 15.5 & 15.0 & 15.4 & 13.6 & 15.0 \\
\hline $\mathrm{Pr}$ & - & - & 3.4 & 3.4 & - & - & 2.6 & 2.6 & - & - \\
\hline Nd & - & 14.4 & 14.4 & 14.4 & - & 13.1 & 12.0 & 12.6 & 8.1 & 13.5 \\
\hline Sm & 2.36 & 2.55 & 2.3 & 2.40 & 4.66 & 4.4 & - & 4.63 & 2.96 & - \\
\hline Eu & 0.55 & 0.67 & - & 0.61 & 1.18 & 1.24 & - & 1.21 & 0.64 & 1.48 \\
\hline Tb & 0.37 & 0.55 & - & 0.46 & 0.99 & 1.18 & - & 1.08 & 0.55 & 1.20 \\
\hline $\mathrm{Yb}$ & 1.06 & 1.28 & - & 1.17 & 4.70 & 4.10 & - & 4.52 & 1.75 & 4.0 \\
\hline Lu & 0.15 & 0.16 & - & 0.155 & 0.73 & 0.80 & - & 0.76 & 0.30 & 0.69 \\
\hline Y & - & - & 39 & 39 & - & - & 27 & 27 & - & - \\
\hline
\end{tabular}

A middle Oligocene lithified sedimentary volcaniclastic breccia (Sample 331-Sample 447A-11-1, 11-15 $\mathrm{cm}$ ), encountered in Hole 447A at the base of the sedimentary column, contains approximately $50 \%$ basaltic and volcanic glass clasts. The matrix consists of clay minerals, iron- and manganese-oxide inclusions, zeolites, and quartz. ${ }^{2}$ The chemical composition of this sample is, in general, similar to basalt (Table 6), although very high contents of $\mathrm{K}_{2} \mathrm{O}$ and $\mathrm{H}_{2} \mathrm{O}$ are its striking feature. The REE distributions, ${ }^{3}$ in spite of basaltic composition, are characterized by high REE concentrations (the sum of $8 \mathrm{REE}=83 \mathrm{ppm}$ ) and by a considerable enrichment in light lanthanides (Table 6, Fig. 1).

The most complete sequence of tuffs dated from the Oligocene is identified at Site 448. Middle Oligocene ashes in the lower portion of the sedimentary and volcaniclastic sequence (at $235-312 \mathrm{~m}$ sub-bottom) vary widely in chemical composition, ranging from acid andesites to basalts. Sample 51 typifies basic ashes that occur in this portion of the tuff sequence (Table 7, Sample 448-28-1, 78-80 cm). The chemical composition of the sample is also marked by a high $\mathrm{H}_{2} \mathrm{O}$ content. It contains about $80 \%$ volcanic glass and about $10 \%$ clay minerals and admixture of ferric hydroxides. The REE concentrations in this sample are relatively low, from 10 to 20 times chondritic value (Table 3 ). However, a chondrite-normalized enrichment in light lanthanides is somewhat higher relative to heavy ones (Table 3). Nevertheless, the effect of the light lanthanide enrichment is considerably less pronounced in this sample compared with that derived from Hole 447A. The chemical composition of ashes at depths less than 235 meters above the seafloor at Site $\mathbf{4 4 8}$ mainly corresponds to dacite. Their mineralogic composition is predominantly volcanic glass. In some instances feldspar and zeolite admixtures are identified. Common clay minerals are normally absent. Microscopic study of only one sample has indicated the presence of $5 \%$ green smectite; the presence of this clay coincides with an abrupt increase in the

\footnotetext{
I In this chapter, samples are referred to by numbers; these samples are also identified in the text and tables by the DSDP system of listing hole-core-section, interval in cm.

2 The mineralogic composition is given on the basis of the lithologic description in the respective site report.

${ }^{3}$ Eight REE = La, Ce, Nd, Sm, Eu, Tb, Yb, and Lu.
}

$\mathrm{K}_{2} \mathrm{O}$ content up to $2.7 \%$ (Sample N47-Sample 448$21-3,1-4 \mathrm{~cm}$ ).

REE distribution in the ash samples (sample 45Sample 448-17-5, 22-24 $\mathrm{cm}$ and sample 47-Sample $448-21-3,1-4 \mathrm{~cm}$ ), although 20 times the chondrite norm, shows no anomaly relative to the REE chondrite distributions (Tables 3 and 7; Fig. 2), i.e., the values are characteristic of the island-arc tholeiitic associations (Jakes and Taylor, 1974).

Hole 450 penetrated the western part of the ash apron in the eastern side of the Parece Vela Basin, which provides evidence of younger volcanism from the West Mariana Ridge (which can be compared to PalauKyushu Ridge volcanism). The middle Miocene vitric tuffs in Hole 450 show little alteration from the chemical composition $\left(\mathrm{SiO}_{2}=56-59 \%\right)$ corresponding to that of andesites.

The tuffs at Hole 450 (Table 8) display a uniform REE content as well as a chemically uniform majorelement composition. The sum of the 8 REE varies from 40 to $48 \mathrm{ppm}$, and their chondrite-normalized distribution compares closely in different samples. The distribution is characterized by an increased light lanthanide enrichment relative to the middle Oligocene ashes encountered in the lower horizons at Hole 448 (Sample 51-Sample 448-28-1, 78-80 cm). A chondrite-normalized concentration curve shows a distinctly steeper curve (Fig. 3). It should be noted that according to the microscopic description of the tuffs at this hole, the secondary mineral content, clays in particular, varies over a wide range and occasionally accounts for a major portion of the tuffaceous sediments (from 8 to $40 \%$ ), resulting in a significantly high $\mathrm{H}_{2} \mathrm{O}^{+}$content.

Drilling at Hole 451 penetrated a thick sequence of upper Miocene tuffs and volcaniclastic breccias derived from the West Mariana Ridge. The sequence represents a younger part of the ash accumulation much closer to the volcanic centers than the ashes of Hole 450. The chemical composition of the volcanic rocks in the cored intervals of the section (Table 9) varies upward from basalts and andesitic basalts (Cores 45 and 34 ) to andesites (Cores 14 and 5). The higher intervals contain a considerable amount of carbonates. Judging from smear slides, the ashes from this hole as well as from Hole 450 , are characterized by a variable content that is locally high in clay minerals $(8-35 \%)$. The REE concen- 


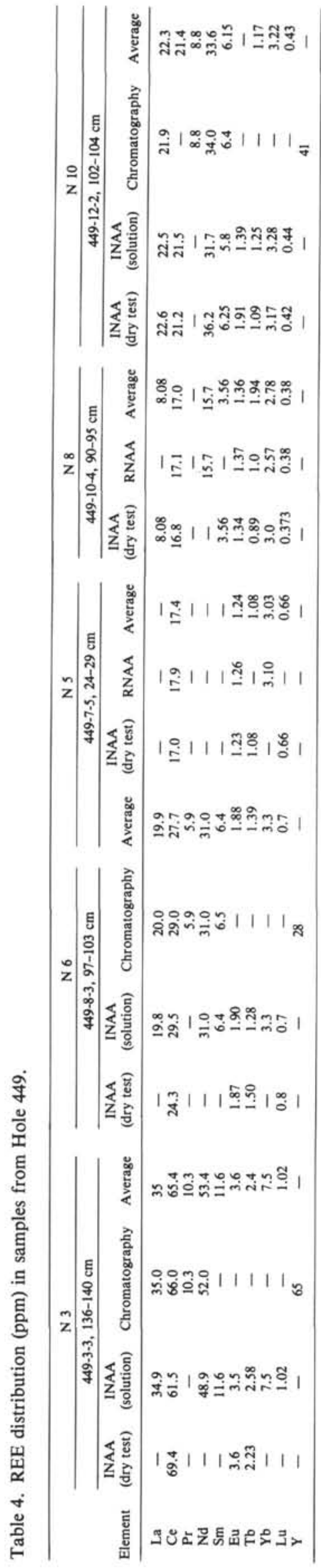

trations in Sample 22 (Sample 451-34-1, 140-150 cm) reach the highest values among the tuff samples studied; the sum of 8 REE amounts to $72 \mathrm{ppm}$. Only a sedimentary volcaniclastic breccia at Hole $447 \mathrm{~A}$ exhibits a somewhat higher composite REE content. However, the sample from Hole 451 displays a significantly higher light lanthanide enrichment compared to the Hole 447A volcaniclastic breccia. The REE distributions versus chondrites (Fig. 4) fully portray the pattern characteristic of the calc-alkaline island-arc associations (Jakes and Taylor, 1974). Another two samples show smaller REE contents and differ in that their chondrite-normalized distribution curves have a more flattened character. These samples exhibit a transitional REE distribution between the values for Sample 22 (Sample 451-34-1, $140-150 \mathrm{~cm}$ ) and the lanthanide distribution patterns in tuffs from Hole 450 (Fig. 4). Analyzing the results enables us to conclude that the REE contents and the REE distribution patterns in the volcanic-ash sediments from the southern part of the Philippine Sea vary from the older Palau-Kyushu Ridge volcanic products to younger West Mariana Ridge ash. Also, there are differences in REE distributions in ashes of different ages within the volcanic debris of both the remnant arcs.

These variations in a suite of ashes of different ages dating from middle Oligocene to late Miocene identify a trend toward greater average REE concentrations in younger tuffs. Also, the REE distributions change from those typical of chondritic patterns of the island-arc tholeiitic associations to those of light lanthanide enrichment typical of island-arc calc-alkalic associations.

These trends are well recognized in Figures 5 and 6, where chondrite-normalized average contents are compared with the data on various island-arc effusive rocks: Eocene volcanic rocks from the island of Eua and Recent rocks from the Tonga (Ewart et al., 1973; Ewart and Bryan, 1972); effusive rocks from Saipan (Taylor, 1968); and andesites and rhyolites from New Zealand (Ewart et al., 1968). These rocks exhibit a whole range of REE distributions varying from the primitive tholeiitic series to the calc-alkalic associations types.

The REE distributions of ashes of the Palau-Kyushu and West Mariana ridges show distinctly transitional values between the tholeiitic effusive rocks of the Eua and Tonga islands and the calc-alkalic volcanic rocks of New Zealand.

The REE distribution tendencies in the rocks analyzed can be interpreted in the light of changes in formation conditions (depth, temperature), a partial melting degree, or contribution of crustal material (possibly sedimentary) to melting products. From this point of view, an analysis of the total REE content ( 8 REE in our case) and of the $\mathrm{La} / \mathrm{Yb}$ ratio curves is of interest. As a rule, the curves show greater values with contribution of crustal material to the rocks. The generalized REE average contents in different shells of the earth were adequately demonstrated by Ronov et al. (1974). A similar diagram is shown in Figure 6. The REE contents of the analyzed tuffs are compared with the published data on the volcanic rocks of the island arcs (the Eua, Tonga, Saipan, and Fiji islands, and New Zealand, showing average values for the tholeiitic and calc-alkalic associa- 
Table 5. REE distribution (ppm) in samples from Holes 450 and 451.

\begin{tabular}{|c|c|c|c|c|c|c|c|c|c|c|c|c|c|c|c|c|}
\hline \multirow[b]{3}{*}{ Element } & \multicolumn{4}{|c|}{$\mathrm{N} 12$} & \multicolumn{3}{|c|}{$\mathrm{N} 15$} & \multicolumn{3}{|c|}{$\mathrm{N} 16$} & \multicolumn{3}{|c|}{$\mathrm{N} 18$} & \multicolumn{3}{|c|}{$\mathrm{N} 22$} \\
\hline & \multicolumn{4}{|c|}{$450-5-2,144-150 \mathrm{~cm}$} & \multicolumn{3}{|c|}{$450-20-1,140-150 \mathrm{~cm}$} & \multicolumn{3}{|c|}{$450-24-3,140-150 \mathrm{~cm}$} & \multicolumn{3}{|c|}{$450-32-3,140-150 \mathrm{~cm}$} & \multicolumn{3}{|c|}{$451-34-1,140-150 \mathrm{~cm}$} \\
\hline & $\begin{array}{c}\text { INAA } \\
\text { (dry test) }\end{array}$ & $\begin{array}{c}\text { INAA } \\
\text { (solution) }\end{array}$ & Chromatography & Average & $\begin{array}{l}\text { INAA } \\
\text { (dry test) }\end{array}$ & RNAA & Average & $\begin{array}{c}\text { INAA } \\
\text { (solution) }\end{array}$ & Chromatography & Average & $\begin{array}{c}\text { INAA } \\
\text { (dry test) }\end{array}$ & RNAA & Average & $\begin{array}{c}\text { INAA } \\
\text { (dry test) }\end{array}$ & $\begin{array}{c}\text { INAA } \\
\text { (solution) }\end{array}$ & Average \\
\hline $\mathrm{La}$ & 20.7 & 18.5 & 21 & 20.1 & 7.9 & - & 7.9 & 7.0 & 8.0 & 7.5 & 8.0 & - & 8.0 & 14.5 & 14.7 & 14.6 \\
\hline $\mathrm{Ce}$ & 34.9 & 35.0 & 42 & 37.3 & 15.0 & 18.0 & 16.5 & 16.6 & 16.8 & 16.7 & .17 .5 & 16.7 & 17.1 & 30.9 & 29.5 & 30.2 \\
\hline Pr & & & 5.6 & 5.6 & & & & & 2.3 & 2.3 & & & & & & \\
\hline Nd & - & 22.7 & 23.0 & 22.8 & 12.0 & 15.6 & 13.8 & 10.8 & 11 & 10.9 & 11.5 & - & 11.5 & 20.8 & 18.6 & \\
\hline $\mathrm{Sm}$ & 4.8 & 4.4 & - & 4.6 & 2.65 & 2.92 & 2.78 & 2.8 & 3.4 & 3.1 & 3.6 & - & 3.6 & 3.80 & 4.29 & 4.04 \\
\hline $\mathrm{Eu}$ & 1.21 & 1.43 & - & 1.32 & 0.88 & 1.00 & 0.94 & 0.84 & - & 0.84 & 0.76 & 1.0 & 0.88 & 1.60 & 1.30 & 1.45 \\
\hline $\mathrm{Tb}$ & 1.32 & 1.42 & - & 1.37 & 0.54 & 0.43 & 0.48 & 0.60 & - & 0.60 & 0.66 & 0.52 & 0.59 & 0.87 & 0.96 & 0.92 \\
\hline $\mathrm{Yb}_{\mathrm{b}}$ & 3.27 & 3.36 & - & 3.32 & 1.75 & 1.89 & $\begin{array}{l}1.82 \\
1.82\end{array}$ & 1.75 & $=$ & 1.75 & 2.00 & 1.87 & 1.94 & 2.12 & 2.45 & 2.29 \\
\hline Lu & 0.57 & 0.51 & - & 0.54 & 0.219 & 0.20 & 0.21 & 0.24 & - & 0.24 & 0.293 & 0.26 & 0.276 & 0.36 & 0.36 & 0.36 \\
\hline $\mathbf{Y}$ & & & 44 & & & & & & 12.2 & & & & & & & 31 \\
\hline
\end{tabular}

Table 6. Instrumental neutron activation analysis (INAA) of rare-earth elements, trace elements, and major elements in the sediments and tuffs of Hole 447A.

\begin{tabular}{|c|c|c|c|c|c|c|c|c|c|c|c|c|c|c|c|c|}
\hline Sample & $\begin{array}{l}\text { Core-Section } \\
\text { (interval in } \mathrm{cm} \text { ) }\end{array}$ & Rock & Age & $\mathrm{Ce}$ & $\mathrm{Eu}$ & $\mathrm{Tb}$ & $\mathrm{Yb}$ & $\mathrm{Lu}$ & Th & $\mathrm{Hf}$ & Sc & $\mathrm{Sb}$ & $\mathrm{SiO}_{2}$ & $\mathrm{Al}_{2} \mathrm{O}_{3}$ & $\mathrm{Fe}_{2} \mathrm{O}_{3}{ }^{\mathrm{a}}$ & $\mathrm{K}_{2} \mathrm{O}$ \\
\hline N 25 & $\begin{array}{l}1-3 \\
98-100\end{array}$ & Pelagic clay & $\begin{array}{l}\text { Early } \\
\text { Miocene }\end{array}$ & 60 & 2.76 & 2.42 & - & 1.18 & 5.6 & 3.2 & 22.6 & 4.4 & 50.6 & 16.8 & $\frac{10.6}{9.2}$ & 2.79 \\
\hline N 26 & $\begin{array}{c}4-3 \\
132-140\end{array}$ & Pelagic clay & $\begin{array}{l}\text { Early } \\
\text { Miocene }\end{array}$ & 62 & 3.89 & 3.68 & 7.21 & 1.06 & 4.4 & 2.1 & 16.1 & 2.9 & 45.2 & 15.0 & $\frac{13.3}{12.7}$ & 3.41 \\
\hline N 28 & $\begin{array}{c}5-5 \\
54-56\end{array}$ & $\begin{array}{l}\text { Carbonate- } \\
\text { bearing clay }\end{array}$ & $\begin{array}{l}\text { Middle } \\
\text { to } \\
\text { Late } \\
\text { Oligocene }\end{array}$ & 32 & 1.20 & - & 2.88 & 0.59 & 0.8 & 2.7 & 18.0 & - & 48.6 & 13.0 & $\frac{7.9}{6.7}$ & 2.81 \\
\hline N 30 & $\begin{array}{c}7-4 \\
80-82\end{array}$ & Clay & $\begin{array}{l}\text { Middle } \\
\text { Oligocene }\end{array}$ & 26 & 1.13 & 1.16 & - & - & 0.8 & 2.5 & 20.3 & 0.9 & 55.4 & 14.8 & $\frac{7.90}{6.3}$ & 2.58 \\
\hline N 32 & $\begin{array}{c}10-1 \\
34-38\end{array}$ & $\begin{array}{l}\text { Variegated } \\
\text { clay }\end{array}$ & $\begin{array}{l}\text { Middle } \\
\text { Oligocene }\end{array}$ & - & 1.90 & 1.59 & - & - & 1.6 & 1.2 & 23.5 & 3.0 & 52.9 & 14.9 & $\frac{12.8}{12.2}$ & 3.87 \\
\hline N 33 & $\begin{array}{l}11-1 \\
11-15\end{array}$ & $\begin{array}{l}\text { Sedimentary } \\
\text { volcaniclastic } \\
\text { breccia }\end{array}$ & $\begin{array}{l}\text { Middle } \\
\text { Oligocene }\end{array}$ & 32 & 1.04 & 1.00 & 2.92 & 0.44 & 1.3 & 2.7 & 20.0 & - & 52.5 & 14.6 & $\frac{8.29}{7.9}$ & 2.31 \\
\hline
\end{tabular}

Note: $\mathrm{Ce}$ through $\mathrm{Sb}$ are given in ppm; $\mathrm{SiO}_{2}$ through $\mathrm{K}_{2} \mathrm{O}$ are given in percentages (data of chemical analyses).

a Numerator shows data obtained by chemical analysis; denominator shows INAA results.

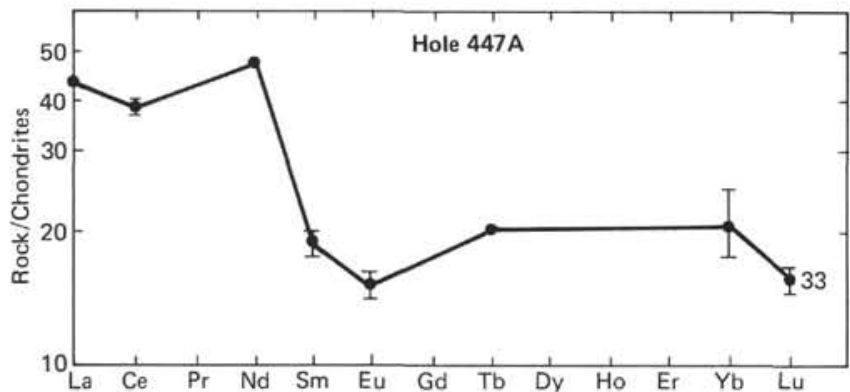

Figure 1. Chondrite-normalized REE distributions for the basaltderived volcaniclastic breccia at Hole 447A. (The sample number used in the text is indicated.)

tions), as well as on oceanic basalts with averages for andesites, and on continental granitic rocks (Ewart and Bryan, 1972; Ewart et al., 1968, 1973; Taylor, 1968; Haskin et al., 1966; Gill, 1973).

Figure 6 indicates that the middle to upper Miocene ashes from Holes 450 and 451 lie on a line that emanates from the zero coordinate and corresponds to the calcalkalic variations of the island-arc volcanic rocks of Fiji and New Zealand with a progressive increase in the $\mathrm{La} / \mathrm{Yb}$ ratio and the sum of $8 \mathrm{REE}$, ultimately trending to granodiorite and granite compositions. The positions of Oligocene tuffs from Site $\mathbf{4 4 8}$ are closer to the positions of oceanic basalts and island-arc tholeiitic basalts, andesites, and dacites from the islands of Eua, Tonga, and Saipan. Differences in the REE content are not significantly similar to chondritic distribution patterns. An analogous relationship persists on the $\mathrm{Ce} / \mathrm{Lu}$ versus the sum of 8 REE curve (Fig. 7). ${ }^{4}$

These differences in the REE distributions in older and younger rocks (if confirmed by more representative material) seem to be somewhat paradoxical from the point of view of the modern models for the formation of the Mariana island-arc system (Karig, 1971). It would be more logical to assume regular changes in REE distribution with the development of both arcs rather than its evolution with time.

However, a dilemma exists: the observed peculiarities of the REE abundances may characterize the original explosive products of these remnant island arcs or many of the peculiarities may result from either low-temperature interaction between ash and seawater or from a sedimentary process.

A general analysis does not appear to confirm that low-temperature alteration processes had a significant effect on the REE distribution. However, some lowtemperature alteration effects are present; e.g., $\mathrm{H}_{2} \mathrm{O}^{+}$ and $\mathrm{K}_{2} \mathrm{O}$ contents in the ashes increase, in general, with

\footnotetext{
4 Classification of tuffs from Holes 450 and 451 as calc-alkalic and tuffs from Holes 448 and $448 \mathrm{~A}$ as tholeitic is confirmed by the seven-component diagram, after the method of Balashov and Sharaskin (Balashov, 1976).
} 
Table 7. INAA of rare-earth, trace, and major elements in Hole 448.

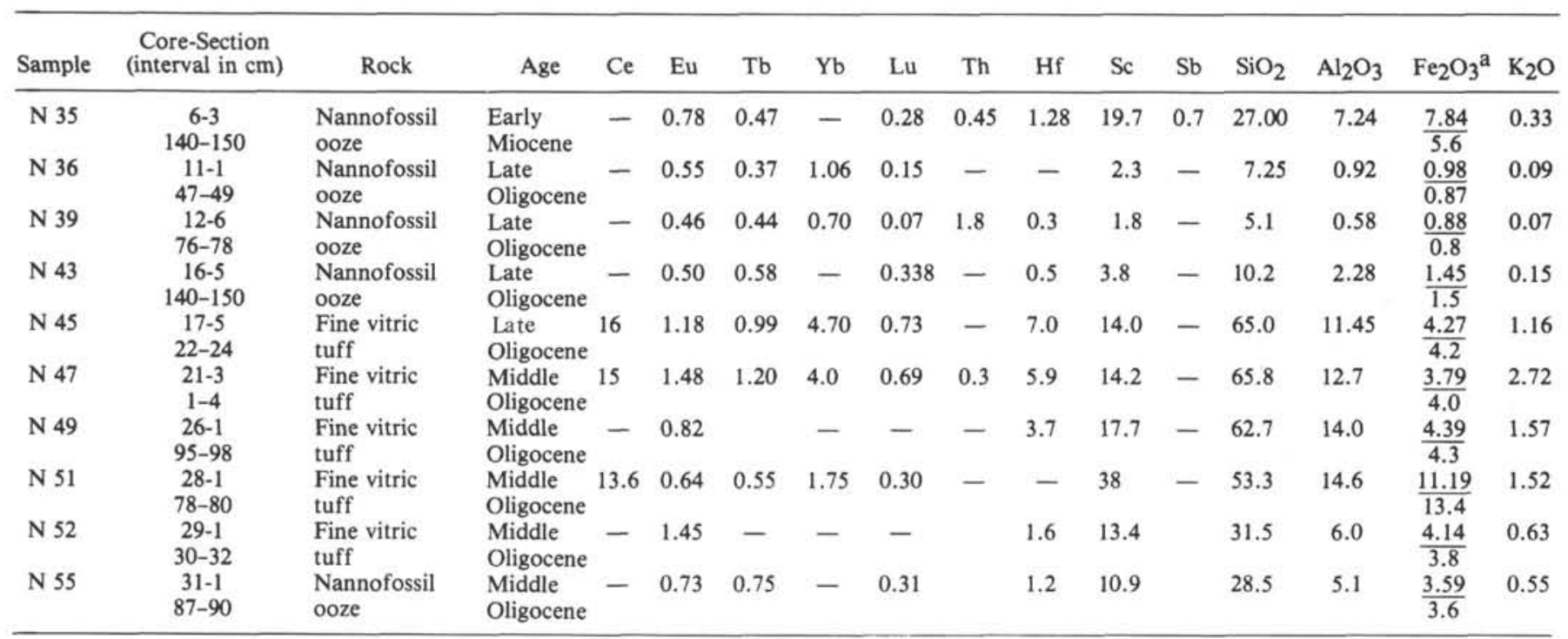

Note: $\mathrm{Ce}$ through $\mathrm{Sb}$ are given in ppm; $\mathrm{SiO}_{2}$ through $\mathrm{K}_{2} \mathrm{O}$ are given in percentages (data of chemical analysis).

a The numerator shows data obtained by chemical analysis; the denominator shows INAA results.

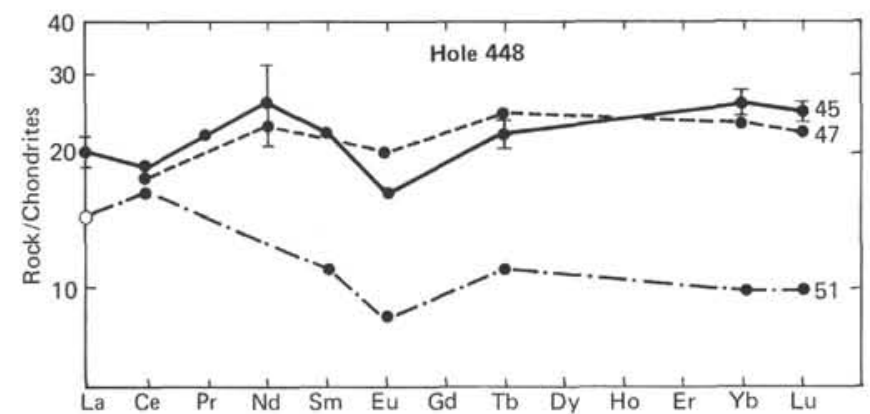

Figure 2. Chondrite-normalized REE distributions for the tuffs at Hole 448. (Sample numbers used in the text are indicated.) their absolute age, i.e., the contents are proportional to the time of their contact with seawater. Meanwhile the data demonstrate various secondary minerals, clays in particular, that are often present in considerable quantities in all tuffs. Because no mineralogic study has been carried out in this study, let us employ the characteristics given in the lithologic descriptions in the site chapters (this volume). The data do not always correspond to the sample intervals for this study and are smear-slide approximations at best. Nevertheless, they can be instrumental, though in a most generalized manner, in identifying the possible correlation between processes that affect the abundance and character of low-temperature minerals and those that affect the REE distribution in the ashes studied.

Figures 8,9 , and 10 show $\mathrm{La} / \mathrm{Yb}, \mathrm{Ce} / \mathrm{Lu}$, and the sum $(\Sigma)$ of 8 REE in tuffs from different sites versus clay mineral content. Rough as they may seem, the rela-

Table 8. INAA of rare-earth, trace, and major elements in Hole 450.

\begin{tabular}{|c|c|c|c|c|c|c|c|c|c|c|c|c|c|c|c|c|}
\hline Sample & $\begin{array}{c}\text { Core-Section } \\
\text { (interval in cm) }\end{array}$ & Rock & Age & $\mathrm{Ce}$ & $\mathrm{Eu}$ & $\mathrm{Tb}$ & $\mathrm{Yb}$ & $\mathrm{Lu}$ & Th & Hf & $\mathrm{Sc}$ & $\mathrm{Sb}$ & $\mathrm{SiO}_{2}$ & $\mathrm{Al}_{2} \mathrm{O}_{3}$ & $\mathrm{Fe}_{2} \mathrm{O}_{3}{ }^{\mathrm{a}}$ & $\mathrm{K}_{2} \mathrm{O}$ \\
\hline N 11 & $\begin{array}{c}1-4 \\
144-150\end{array}$ & Pelagic clay & Pleistocene & 63 & 1.98 & 1.06 & 4.04 & & 8.9 & 3.3 & 21.9 & - & 50.8 & 17.05 & $\frac{11.95}{10.4}$ & 2.18 \\
\hline $\mathrm{N} 12$ & $\begin{array}{c}5-2 \\
144-150\end{array}$ & $\begin{array}{l}\text { Ash-bearing } \\
\text { pelagic clay }\end{array}$ & $\begin{array}{l}\text { Late } \\
\text { Miocene }\end{array}$ & 35 & 1.21 & 1.32 & 3.27 & 0.57 & 2.6 & 3.0 & 19.6 & - & 59.8 & 15.05 & $\frac{8.21}{7.4}$ & 1.81 \\
\hline N 13 & $\begin{array}{c}12-2 \\
140-150\end{array}$ & Vitric tuff & $\begin{array}{l}\text { Middle } \\
\text { Miocene }\end{array}$ & 17 & 1.02 & - & 1.80 & 0.34 & 1.2 & 3.0 & 12.2 & - & 58.9 & 14.70 & $\frac{4.66}{5.6}$ & 1.66 \\
\hline N 15 & $\begin{array}{c}20-1 \\
140-150\end{array}$ & Vitric tuff & $\begin{array}{l}\text { Middle } \\
\text { Miocene }\end{array}$ & 15 & 0.88 & 0.54 & 1.75 & 0.22 & 1.1 & 2.7 & 24.7 & - & 56.30 & 14.80 & $\frac{8.35}{8.2}$ & 1.37 \\
\hline N 16 & $\begin{array}{c}24-3 \\
140-150\end{array}$ & Vitric tuff & $\begin{array}{l}\text { Middle } \\
\text { Miocene }\end{array}$ & - & - & - & - & - & - & - & - & - & 54.3 & 15.60 & 9.32 & 1.17 \\
\hline N 18 & $\begin{array}{c}32-3 \\
140-150\end{array}$ & Vitric tuff & $\begin{array}{l}\text { Middle } \\
\text { Miocene }\end{array}$ & 17 & 0.76 & 0.66 & 2.00 & 0.29 & 1.2 & 2.9 & 19.6 & - & 54.4 & 12.50 & $\frac{7.21}{6.56}$ & 1.32 \\
\hline
\end{tabular}

Note: $\mathrm{Ce}$ through $\mathrm{Sb}$ are given in ppm; $\mathrm{SiO}_{2}$ through $\mathrm{K}_{2} \mathrm{O}$ are given in percentages (data of chemical analysis).

a The numerator shows data obtained by chemical analysis; the denominator shows INAA results. 


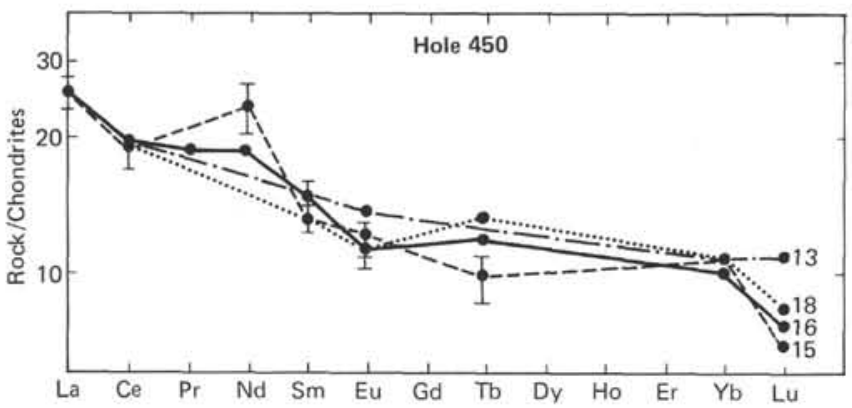

Figure 3. Chondrite-normalized REE distributions for the tuffs at Hole 450. (Sample numbers used in the text are indicated.)

tionships appear to be comparable (although to various degrees in tuffs from different sites). We may conclude that the contribution of clay minerals during ash sedimentation or the authigenic formation by reaction of ash with interstitial waters (see the chapter on isotopic composition by Migdisov et al., this volume) exerts strong control over changes in the primary REE distribution patterns in the ashes. Preliminary calculations indicate that the REE distribution in the Hole 447A sample derived from sedimentary breccia, comprising altered basalt and clay matrix with iron and manganese hydroxides (ratio 40:60), is the same as that in compositions of middle-Oligocene altered basaltic ash from Hole 448 (Sample 51) and variegated clay (85.0-87.1 m sub-bottom) overlying the breccia. A similar REE distribution pattern may be obtained by adding $10 \%$ of the clay material to the REE composition of Sample 51, which has a slight light REE enrichment pattern. Although these patterns are similar, the sum of the 8 REE is approximately twice as great as the sedimentary breccia. The lower the REE concentration in the source ash material, the more sensitive it is to exogenic changes or the stronger the effect of low-temperature minerals is. This phenomenon is illustrated by the persistence of the primary REE distribution patterns in dacites and greater compositional changes in the ashes of basaltic and andesitic composition. However, if the variegated clay is not from another source but actually is altered tuff (see Site 448 report, this volume), then this line of reasoning must be reversed. We could then conclude that low-temperature alteration of ashes to clays has changed the REE distribution.

Figures 8,9 , and 10 show differentiation in the total REE contents and differences in the character of the REE distribution in ash material of various holes before alteration of the material or before contribution of sediments. In addition, it appears that the original differences in REE abundances are considerably smaller and that a greater shift toward a calc-alkalic type of distribution has been exhibited by the ashes at Hole 450 than by the ashes at Hole 451 .

It is also possible that low-temperature processes may have effected the primary REE distributions in tuffs so that cerium anomalies may have been created during oxidation of the ashes. A comparison of the cerium oxidation effect or cerium anomaly $\left(\mathrm{Ce} / \mathrm{Ce}\right.$, where $\mathrm{Ce}^{*}$ is the estimated value for $\mathrm{Ce}$ based on the smooth normalized REE curve and $\mathrm{Ce}$ is the measured value, which significantly departs from the smooth curve in many cases) with the oxidation state of iron expressed as $\mathrm{FeO} / \mathrm{Fe}_{2} \mathrm{O}_{3}$ has confirmed the fact that selective cerium enrichment occurs with increased iron oxidation in the ashes (Fig. 11). This effect becomes most readily recognized where $\mathrm{FeO} / \mathrm{Fe}_{2} \mathrm{O}_{3}=0.5$ in the tuffs.

Let us outline the distribution patterns of some other trace elements. Yttrium contents were determined only for four tuff samples, including the sedimentary breccia from Hole 447A. Naturally, there is a close relationship between the yttrium concentrations and the total REE content in the tuffs. Also, a relationship between the yttrium concentrations and the iron and magnesium contents emerges. An increase in clay minerals in the ashes is correlated with relevantly higher yttrium concentrations.

More information is available on Sc distributions in tuffs, which correlate closely with iron concentrations in these rocks (Fig. 12). The $\mathrm{Sc} / \mathrm{Fe}$ ratio is higher in the ashes than in the clay sediments. The similar differentiation between tuffs and clays is unavailable for magnesium, which also exhibits some correlation with scandium.

Thorium concentrations do not tend to increase with either a higher silicon or higher potassium content. On the contrary, an inverse relationship is observed. In-

Table 9. INAA of rare-earth, trace, and major elements in Hole 451.

\begin{tabular}{|c|c|c|c|c|c|c|c|c|c|c|c|c|c|c|c|c|}
\hline Sample & $\begin{array}{c}\text { Core-Section } \\
\text { (interval in } \mathrm{cm} \text { ) }\end{array}$ & Rock & Age & $\mathrm{Ce}$ & $\mathrm{Eu}$ & $\mathrm{Tb}$ & $\mathrm{Yb}$ & Lu & Th & $\mathrm{Hf}$ & Sc & $\mathrm{Sb}$ & $\mathrm{SiO}_{2}$ & $\mathrm{Al}_{2} \mathrm{O}_{3}$ & $\mathrm{Fe}_{2} \mathrm{O}_{3}{ }^{\mathrm{a}}$ & $\mathrm{K}_{2} \mathrm{O}$ \\
\hline N 19 & $\begin{array}{c}2-4 \\
140-150\end{array}$ & $\begin{array}{l}\text { Nannofossil- } \\
\text { foraminifer } \\
\text { ooze }\end{array}$ & Quaternary & - & 0.57 & 0.47 & 2.46 & 0.39 & 0.9 & 0.9 & 10.0 & 0.9 & 17.3 & 5.70 & $\frac{3.63}{3.7}$ & 0.32 \\
\hline N 20 & $\begin{array}{c}5-3 \\
140-150\end{array}$ & $\begin{array}{l}\text { Carbonate- } \\
\text { bearing } \\
\text { vitric tuff }\end{array}$ & $\begin{array}{l}\text { Late } \\
\text { Miocene }\end{array}$ & 18 & 0.88 & 0.52 & 2.0 & 0.30 & 1.1 & 3.2 & 24.5 & 1.2 & 17.5 & 14.45 & $\frac{8.1}{7.76}$ & 1.06 \\
\hline N 21 & $\begin{array}{c}14-1 \\
140-150\end{array}$ & $\begin{array}{l}\text { Carbonate- } \\
\text { bearing } \\
\text { vitric tuff }\end{array}$ & $\begin{array}{l}\text { Late } \\
\text { Miocene }\end{array}$ & 22 & 0.98 & 0.77 & 2.20 & 0.34 & 1.7 & 2.0 & 18.0 & - & 52.4 & 15.4 & $\frac{5.6}{5.48}$ & 1.26 \\
\hline N 22 & $\begin{array}{c}34-1 \\
140-150\end{array}$ & Vitric tuff & $\begin{array}{l}\text { Late } \\
\text { Miocene }\end{array}$ & 31 & 1.60 & 0.87 & 2.13 & 0.36 & 1.5 & 1.3 & 26.7 & - & 53.2 & 18.2 & $\frac{9.4}{8.6}$ & 0.81 \\
\hline
\end{tabular}

Note: $\mathrm{Ce}$ through $\mathrm{Sb}$ are given in ppm; $\mathrm{SiO}_{2}$ through $\mathrm{K}_{2} \mathrm{O}$ are given in percentages (data of chemical analysis).

a Numerator shows data obtained by chemical analysis; denominator shows INAA results. 


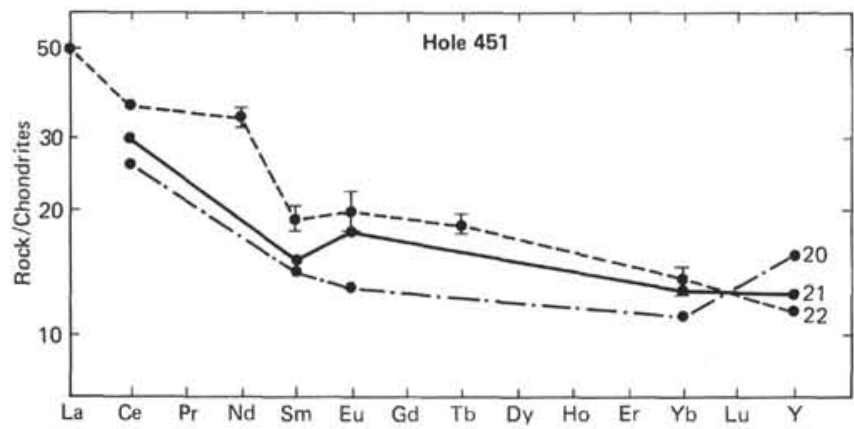

Figure 4. Chondrite-normalized REE distributions for the tuffs at Hole 451. (Sample numbers used in the text are indicated.)

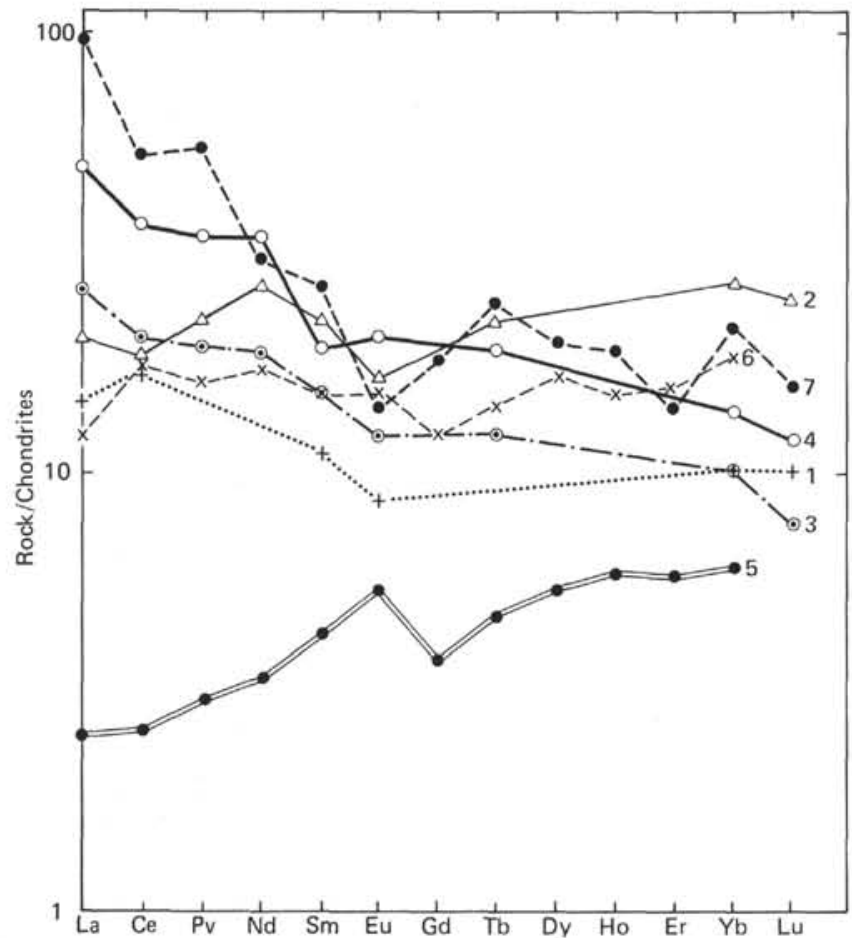

Figure 5. REE distribution patterns for the tuffs at Holes 448,450 , and 451 compared to those for the volcanic rocks from other island-arc systems. $(1=$ Sample 51 [448-28-1 78-80 cm, middle Oligocene]; 2 = Sample 45 [448-17-5, 22-24 cm, late Oligocene]; 3 $=$ Sample 16 [450-24-3, 140-150 cm, middle Miocene]; $4=$ Sample 22 [451-34-1, 140-150 cm, early Miocene]; 5 = basalt from the Eua [Ewart and Bryan, 1972]; 6 = dacite from the Tonga [Ewart et al., 1973]; and 7 = rhyolite from New Zealand [Ewart et al., 1968].)

creased thorium concentrations are correlated with higher aluminum concentrations in the tuffs (Fig. 13). Moreover, three concentration levels of both elements are identified; the lowest values are found in Oligocene tuffs at Site 448, intermediate levels are observed in the middle-Miocene tuffs at Site 450, and the highest figures are obtained for the upper Miocene ashes at Site 451 . Thorium concentration tends to increase with an increased iron content. Thorium enrichment in tuffs parallels greater $\mathrm{La} / \mathrm{Yb}$ (or $\mathrm{Ce} / \mathrm{Lu}$ ) ratios (Fig. 14).

In contrast to thorium, hafnium accumulates in more silicic tuffs (Fig. 15). Higher $\mathrm{Fe}$ and $\mathrm{Mg}$ content is cor-

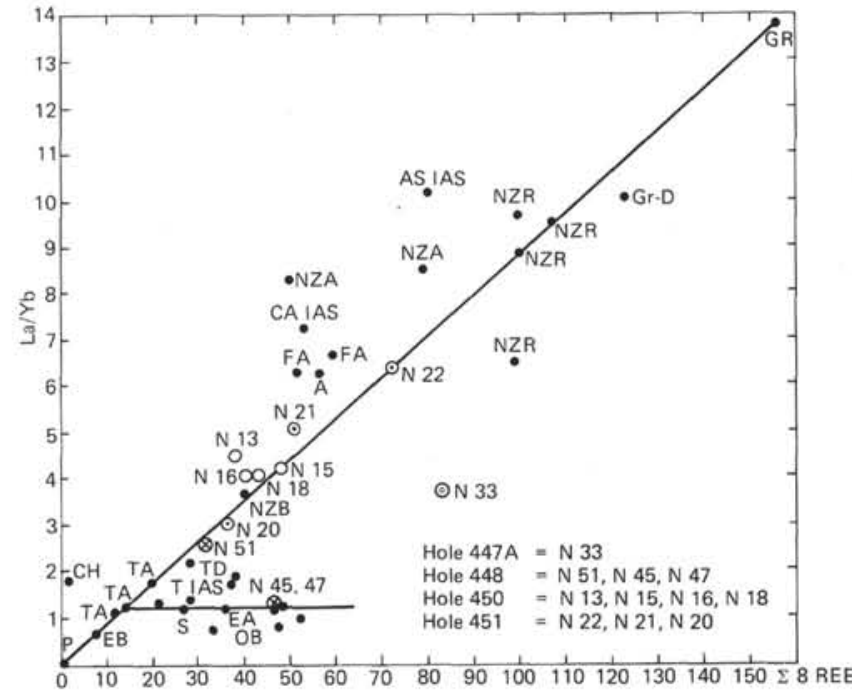

Figure $6 . \mathrm{La} / \mathrm{Yb}$ and the sum $(\Sigma)$ of 8 REE in the volcanic debris of Leg 59 samples, in the effusive rocks of the island arcs, and in continental acid rocks. (Symbols: $\otimes=$ ashes, Hole 448; $($ ) = basaltderived volcaniclastic breccia, Hole 447A; $O=$ ashes, Hole 450; $\odot=$ ashes, Hole 451. Data from the literature: $\mathrm{P}=$ hightemperature peridotites; $\mathrm{CH}=$ chondrites; $\mathrm{OB}=$ oceanic basalts; $\mathrm{Gr}-\mathrm{D}=$ granodiorites; $\mathrm{Gr}=$ granites [Haskin et al., 1966]; $\mathrm{S}=$ andesites from the Saipan; $A=$ average for andesites [Taylor, 1968); $\mathrm{EB}=$ basalts from the Eua; $\mathrm{EA}=$ andesites from Eua [Ewart and Bryan, 1972]; TA = andesites from Tonga; TD = dacites from the Tonga [Ewart et al., 1973]; FA = andesites from Fiji [Gill, 1973]; NZA = andesites from New Zealand; NZR = rhyolites from New Zealand; NZB = basalts from New Zealand [Ewart et al., 1968]; AS IAS = alkaline-shoshonitic island-arc associations; CA IAS = calc-alkalic island-arc associations; and T IAS $=$ tholeitic island arc associations [Jakes and Gill, 1970].)

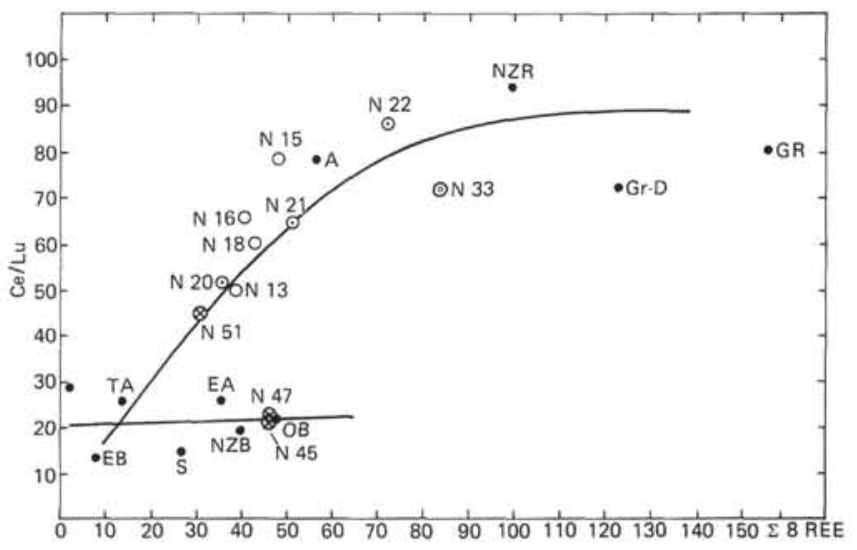

Figure 7. Ce/Lu and the sum of $8 \mathrm{REE}$ in the ashes of Leg 59 samples, in the volcanic rocks of the island arcs, and in continental granitic rocks. (The symbols of Fig. 6 are used; sample numbers used in the text are indicated.)

related with an abrupt diminution in hafnium concentrations (Fig. 16).

Table 10 presents general trends in Th, Hf, and Sc concentration patterns in volcanic tuffs of different ages and their relationships with REE. This table confirms once more that the distribution of $\mathrm{Th}, \mathrm{Hf}$, and Sc characterizes various aspects of tuff evolution in the southern part of the Philippine Sea. Thorium, as was men- 


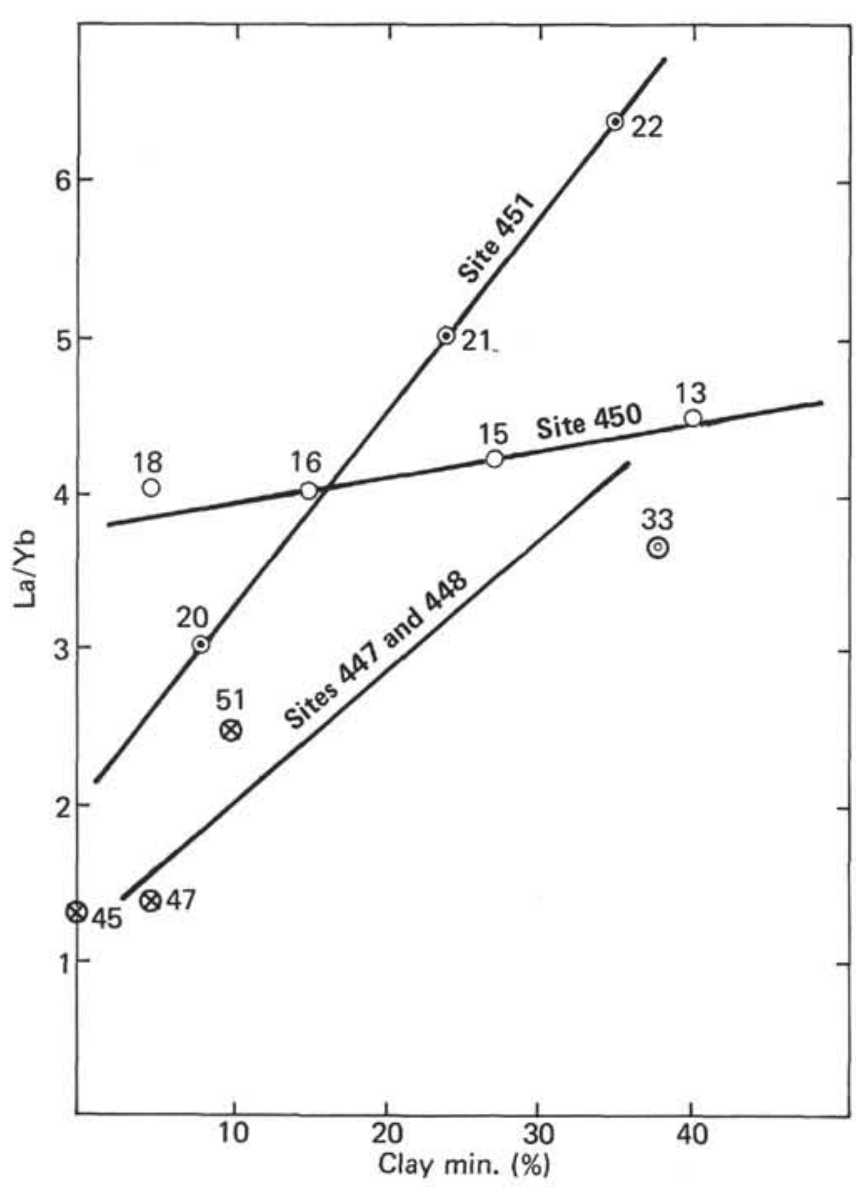

Figure $8 . \mathrm{La} / \mathrm{Yb}$ in Sites 447 through 451 tuffs relative to clay mineral content. (The symbols are the same as those in Fig. 6.)

tioned previously, characterizes involvement of crustal material and accumulates with diminution of the age of the ash layers from middle Oligocene to late Miocene. The correlation of the abundance of this element with the clay mineral content is not so striking as for the $\mathrm{La} / \mathrm{Yb}$ ratio. Thus thorium distributions alone do not provide enough evidence to solve the problem, whether crustal material has been contributed to the magmas during melting, whether the Th was derived during sedimentation, or whether the Th was introduced by secondary ash alteration.

$\mathrm{Hf}$ and $\mathrm{Sc}$ contents distinctly reflect changes in the petrochemical composition of the ashes analyzed and reveal that they change from basic in the middle Oligocene to salicic in the late Oligocene, and from andesitic in the middle Miocene to more basic in the late Miocene. $\mathrm{Sc}$ and $\mathrm{Hf}$ are inversely related. Increased concentrations of Sc indicate an increase in basic (and those of $\mathrm{Hf}$ an increase in salicic) character of the ashes, following the geochemical behavior of these elements.

\section{TRACE ELEMENTS IN SEDIMENTARY ROCKS}

The distribution of trace elements was studied in 21 samples from five holes of Leg 59 . However, equally detailed analyses were not carried out for all of them. Nine samples were analyzed for the contents of 8 or more REE, whereas the rest of the samples were studied

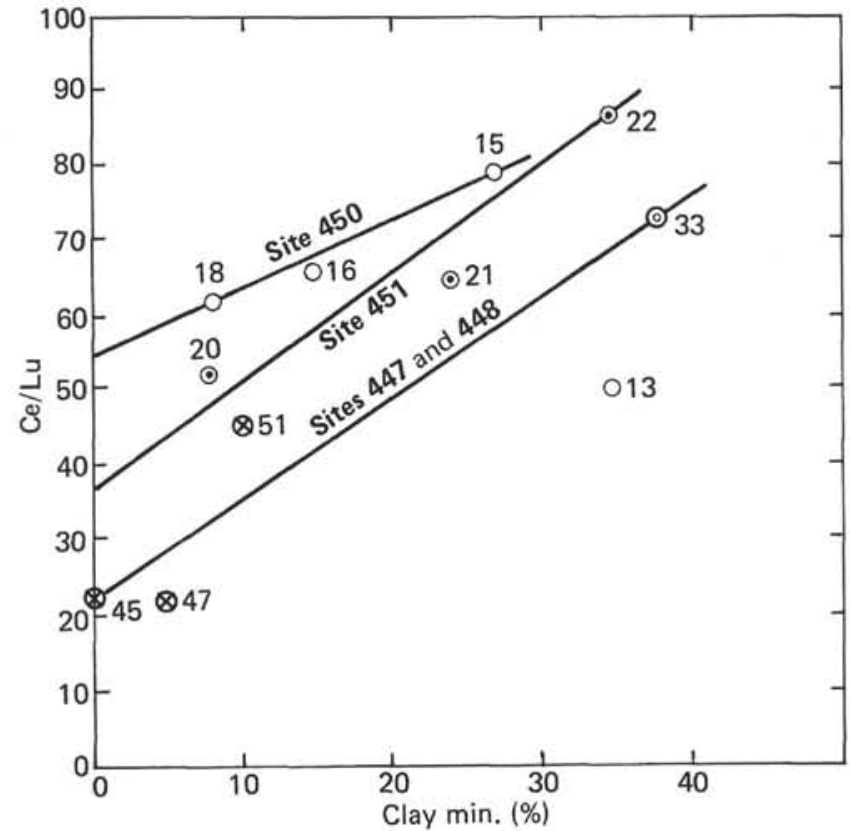

Figure 9. $\mathrm{Ce} / \mathrm{Lu}$ in Sites 447 through 451 tuffs relative to clay mineral content. (See Fig. 6 for identification of symbols denoting samples from the Leg 59 sites.)

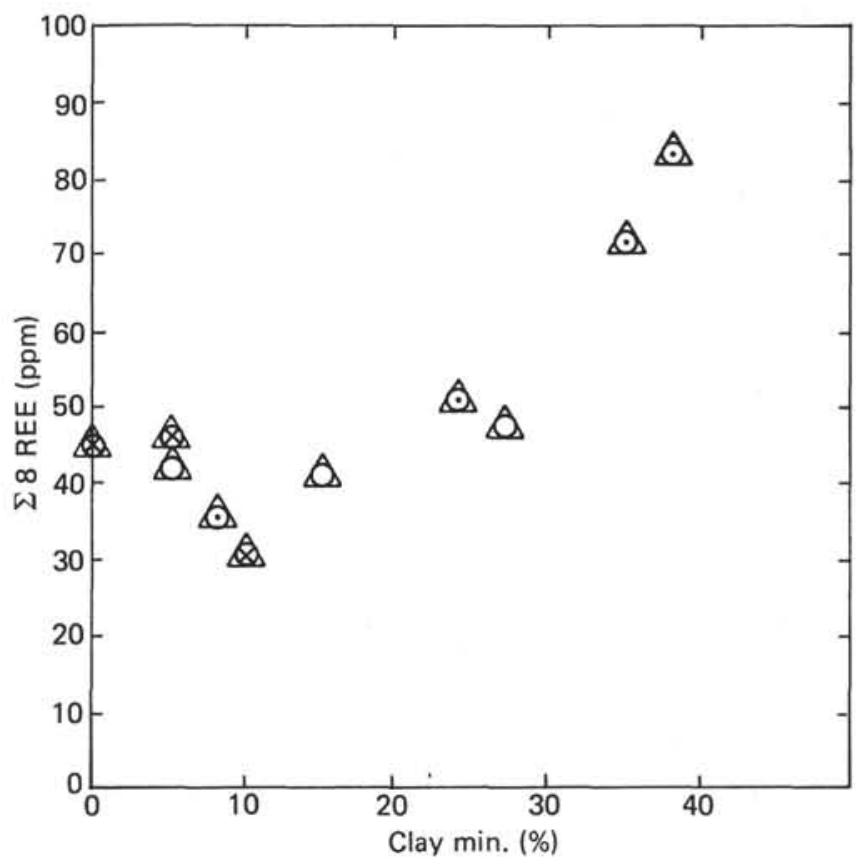

Figure 10. REE content (sum of 8 REE) in Sites 447 through 451 tuffs relative to clay mineral content. (See Fig. 12 to identify symbols.)

to obtain data only on 3 to 5 lanthanides. The most complete information on abundances and distribution patterns of REE was obtained for the sediments of the inter-arc basins (Holes 447A and 449).

The REE distributions in the sediments studied (Figs. 17-21) were normalized relative to North American shales (Haskin et al., 1966). To determine the role of 


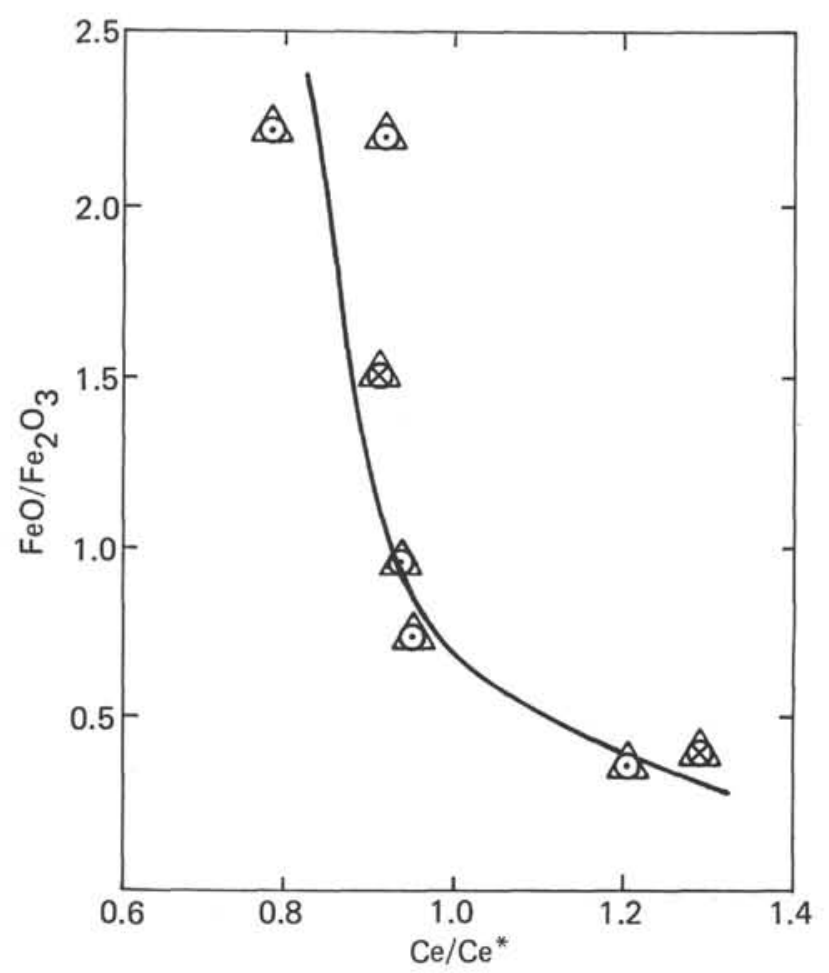

Figure 11. $\mathrm{Ce} / \mathrm{Ce} *$ in Sites 447 through 451 tuffs relative to $\mathrm{FeO} / \mathrm{Fe}_{2} \mathrm{O}_{3}$. ( $\mathrm{Ce}^{*}$ is the estimated value for Ce based on the smooth normalized REE curve; $\mathrm{Ce}$ is the measured value, a significant departure from the smooth curve in many cases. See Fig. 12 for symbol meanings.)

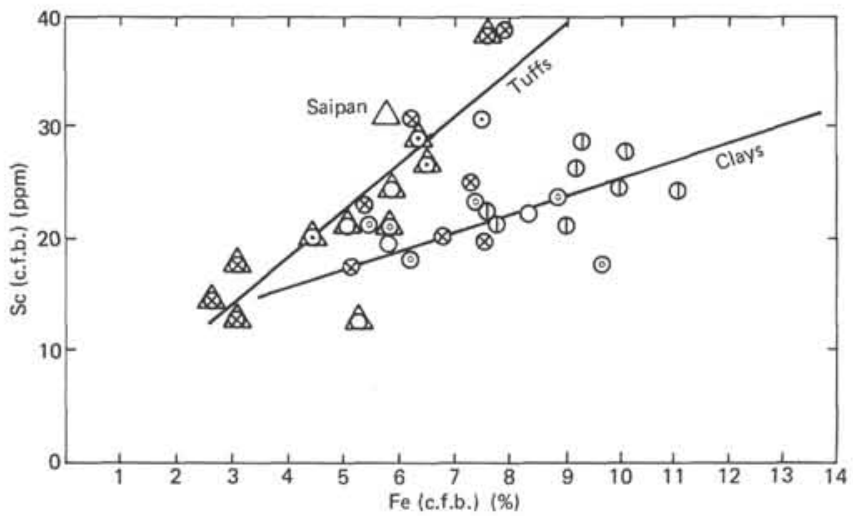

Figure 12. Sc and Fe relationship (calculated on a carbonate-free basis [c.f.b.] in the tuffs and sediments at Hole $447 \mathrm{~A}$ through 451 . (Symbols: $($ ) $=$ Hole 447A; $\otimes=$ Hole $448 ;(1)=$ Hole $449 ; O=$ Hole 450; $\odot=$ Hole 451. The tuffs from these holes are indicated by triangles; clays have no triangles.)

volcanic material in lanthanide distribution in the sediments, the same normalization was used for the tuffs.

Fig. 17 shows REE distribution in various units in Hole 447A sediments (from the sedimentary apron on the western side of the Palau-Kyushu Ridge in the West Philippine Basin), including a sedimentary breccia at the base of the sedimentary section. The differences in REE concentrations and correlations between the lowerMiocene sediments (i.e., pelagic clays that form Unit I) and the underlying middle to upper Oligocene sediments (Units 2-5) are well displayed. The REE contents

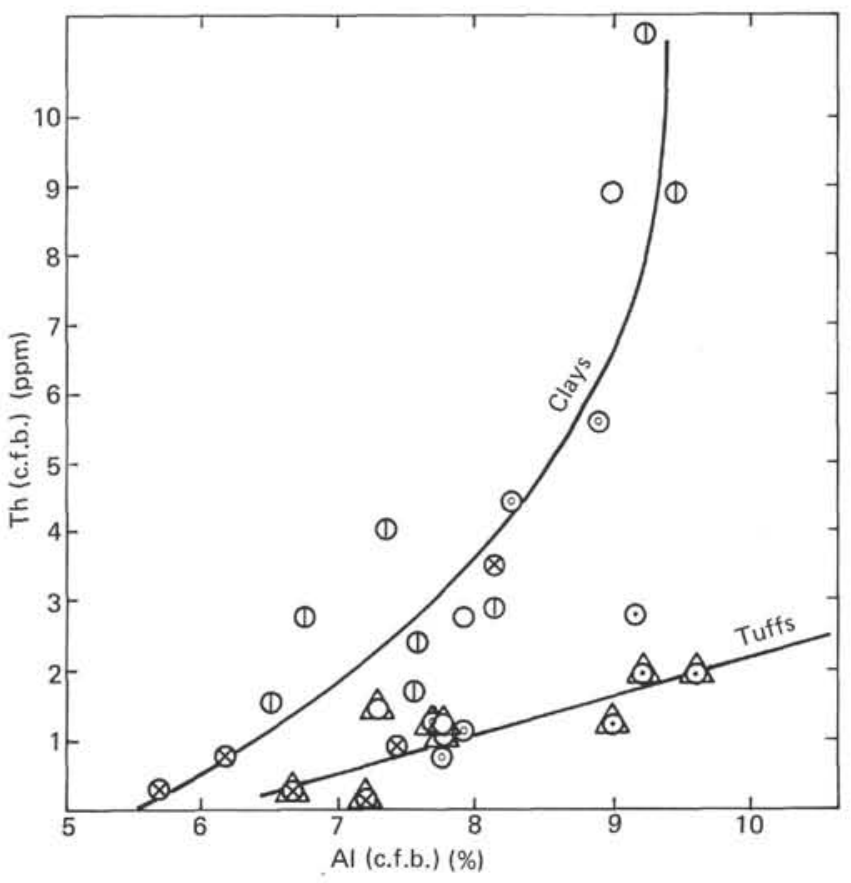

Figure 13. Correlation between $\mathrm{Th}$ and $\mathrm{Al}$ concentrations (calculated on a carbonate-free basis [c.f.b.]) in cores from Hole 447A through 451. (See Fig. 12 for identification of symbols.)

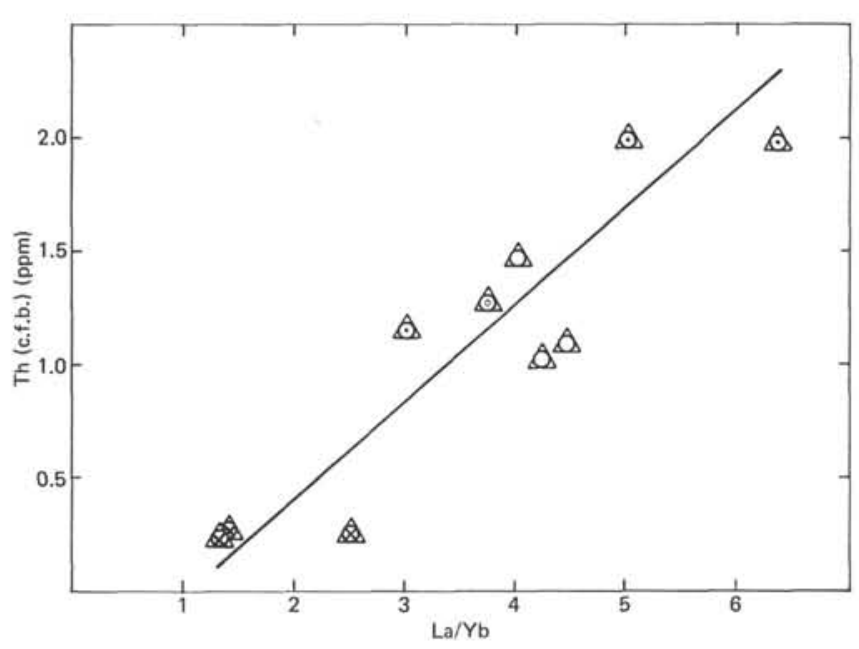

Figure 14. Th content and $\mathrm{La} / \mathrm{Yb}$ (calculated on a carbonate-free basis [c.f.b.]) in the tuffs at Hole 447A through 451. (The symbols are the same as in Fig. 12.)

and the distributions in the latter are practically indistinguishable from those of the basal volcaniclastic breccia. A similar relationship, to a certain extent, is demonstrated by the mineralogic composition of the lithologic units. In Unit 1 there is virtually no volcaniclastic admixture, whereas iron-manganese micronodules (up to $8 \%$, iron hydroxides (up to $10 \%$ ), zeolites (up to $10 \%$ ), and fish fossils (up to $6 \%$ ) contribute significantly to mineral content in addition to clays.

In the lower units of Oligocene age, a volcanic glass admixture locally reaches $80 \%$ (Unit 3 ), and iron hydroxides and micronodules are found in negligible amounts. The layer of variegated clay overlying the 


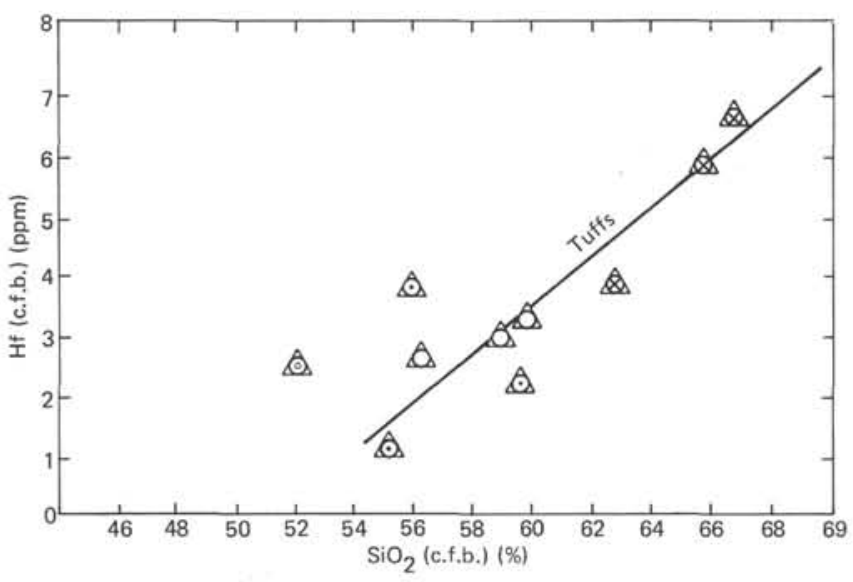

Figure 15. $\mathrm{Hf}$ and $\mathrm{SiO}_{2}$ relationship (calculated on a carbonate-free basis [c.f.b.]) in the tuffs at Hole 447A through 451. (See Fig . 12 for symbol identification.)

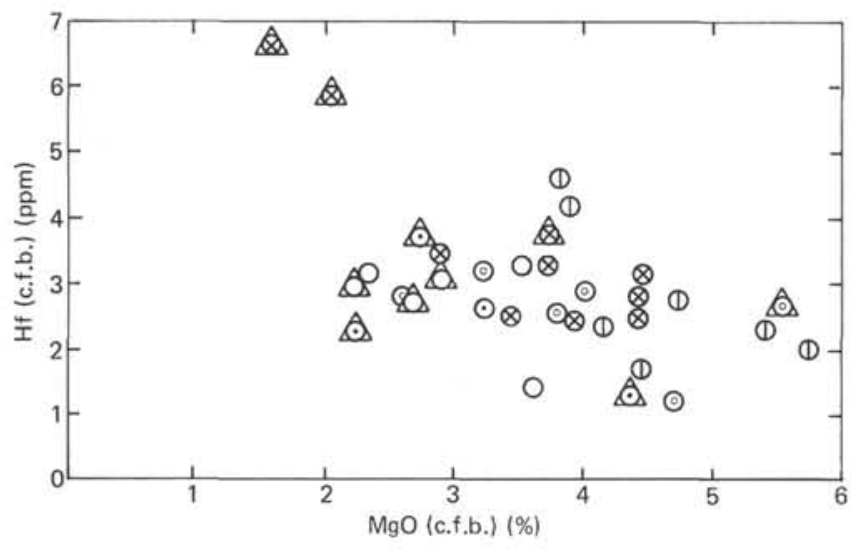

Figure 16. Hf concentration (calculated on a carbonate-free basis [c.f.b.]) relative to $\mathrm{MgO}$ content in the tuffs at Holes $447 \mathrm{~A}$ through 451. (See Fig. 12 for identification of the symbols.)

breccia (Unit 4) exhibits some of the peculiarities close to those in the upper unit, specifically, the overwhelming predominance of clay and a considerable amount of iron-manganese micronodules. However, if this unit is an altered ash, as interpreted in the Site 447 report (this volume), then these data may be interpreted differently.

Site 448 sediments characterize Oligocene sedimentation within a remnant island arc (the Palau-Kyushu Ridge). The carbonate sediments of the upper unit of this hole (Fig. 18), incorporating biogenic carbonate upper Oligocene, early Miocene, and middle Miocene sediments, appear to display uniform REE distribution patterns. Minor differences are a function of variable amounts of the insoluble residue in the carbonates $\left(\mathrm{CO}_{2}\right.$ $=20-40 \%$ ), a slightly differentiated enrichment in the heaviest lanthanides ( $\mathrm{Yb}$ and $\mathrm{Lu})$, and possibly a variable Ce depletion. The last observation, however, cannot be adequately substantiated because a whole range of lanthanides was obtained only for one carbonate sample from this hole (Sample 36-Sample 448-11-1, 47-49 cm). Nevertheless, this particular sample shows a considerable $\mathrm{Ce}$ depletion, which usually is associated with variable amounts of carbonate skeletons of pelagic organisms (Piper, 1974). Judging from the similarity of REE distributions, this depletion might occur in other samples from this unit. At the same time, Sample 36 does not show any Eu anomaly.

The distribution of medium and heavy lanthanides in the carbonates of the second lithologic unit (Unit 2) closely approximates the picture obtained for dacite volcanic ash from this unit (Sample 45). This distribution is characterized by a relative progressive enrichment from medium to heavy REE. Accordingly, the carbonates from the lower parts of this hole (middle Oligocene Units 4 and 5) display a REE range (Sample 55) actually unrecognizable from that in the tuffs derived from this part of the sedimentary cover (the PalauKyushu Ridge).

The sediments from the western part of the inter-arc Parece Vela Basin are represented in Hole 449. Pleistocene and upper Miocene(?) sediments (Samples 1-4, Table 11) in the upper lithologic unit (Unit 1) consist of pelagic clays and are mineralogically and compositionally uniform, containing clay minerals with minor admixtures of iron hydroxides, micronodules, fish fossils, and zeolites. However, the sediments differ in REE concentrations from those discussed earlier (Fig. 19). There is only a small range of values in the REE distribution patterns, which display an enrichment in heavy lanthanides, relatively low contents of light elements, and no cerium depletion. Only the sample derived from the base of the unit is assumed to exhibit a considerable cerium depletion. The REE distribution in this sample is very similar to that in a sample obtained from the underlying middle Miocene carbonate unit (Unit 2; Sample 5-Sample 449-7-5, 24-29 cm; Fig. 19; Table 11) calculated on a carbonate-free basis.

Lower Miocene pelagic clays of Unit 4 consist of clay minerals with admixtures of iron hydroxides, ironmanganese micronodules, and considerable amounts of volcanic glass in many cases. In individual layers the

Table 10. Average contents (ppm) of trace elements and their correlation in the volcanic tuffs at Sites 447 through $451^{\mathrm{a}}$.

\begin{tabular}{|c|c|c|c|c|c|c|c|c|c|c|c|c|c|c|c|}
\hline Site & Age & $\mathrm{La}$ & $\mathrm{Ce}$ & $\mathrm{Nd}$ & $\mathrm{Sm}$ & $\mathrm{Eu}$ & $\mathrm{Tb}$ & $\mathrm{Yb}$ & $\mathrm{Lu}$ & REE & $\mathrm{La} / \mathrm{Yb}$ & $\mathrm{Ce} / \mathrm{Lu}$ & $\mathrm{Th}$ & $\mathrm{Hf}$ & $\mathrm{Sc}$ \\
\hline 447 & Middle Oligocene & 4.4 & 13.6 & - & 2.36 & 0.64 & 0.55 & 1.75 & 0.30 & 31 & 2.51 & 45.2 & 0.3 & - & 40 \\
\hline 448 & Early Oligocene & 5.8 & 15.2 & 13.0 & 4.56 & 1.34 & 1.14 & 4.26 & 0.74 & 46 & 1.36 & 20.7 & 0.3 & 6.4 & 14.1 \\
\hline 450 & Middle Miocene & 7.8 & 16.8 & 13.3 & 3.16 & 0.92 & 0.56 & 1.84 & 0.27 & 45 & 4.24 & 63.2 & 1.2 & 2.9 & 18.8 \\
\hline 451 & Early Miocene & 11.9 & 25.9 & 13.1 & 3.3 & 1.26 & 0.79 & 2.35 & 0.38 & 59 & 5.06 & 67.8 & 1.6 & 2.5 & 25.6 \\
\hline
\end{tabular}

a Average REE values for samples containing carbonate admixtures were calculated on a carbonate-free basis. Concentrations of the element omitted from the analysis were obtained through interpolation to chondrite-normalized REE contents. 


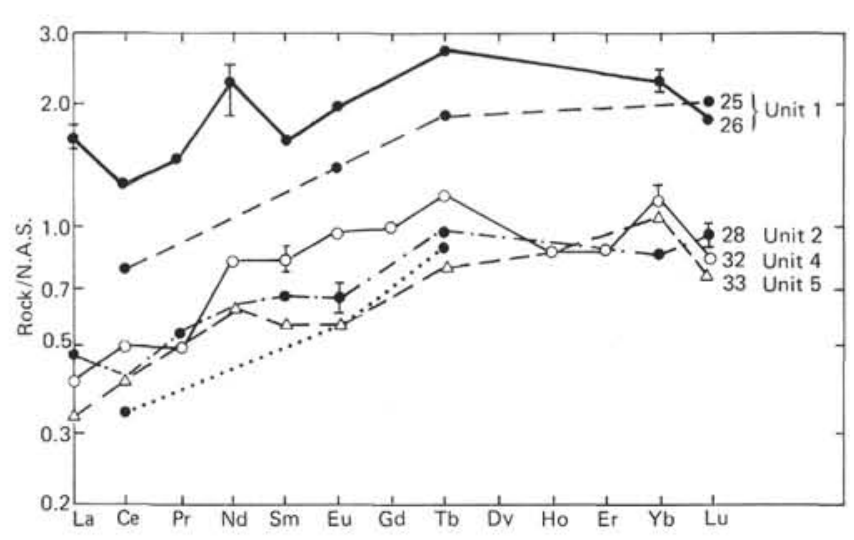

Figure 17. North American shale-normalized REE distribution in the sediments at Hole 447A. (The sample numbers used in the text are represented by symbols, as indicated. N.A.S. = North American shale; Units 1, 2, 4, and 5 refer to unit numbers used in the site report, this volume.)

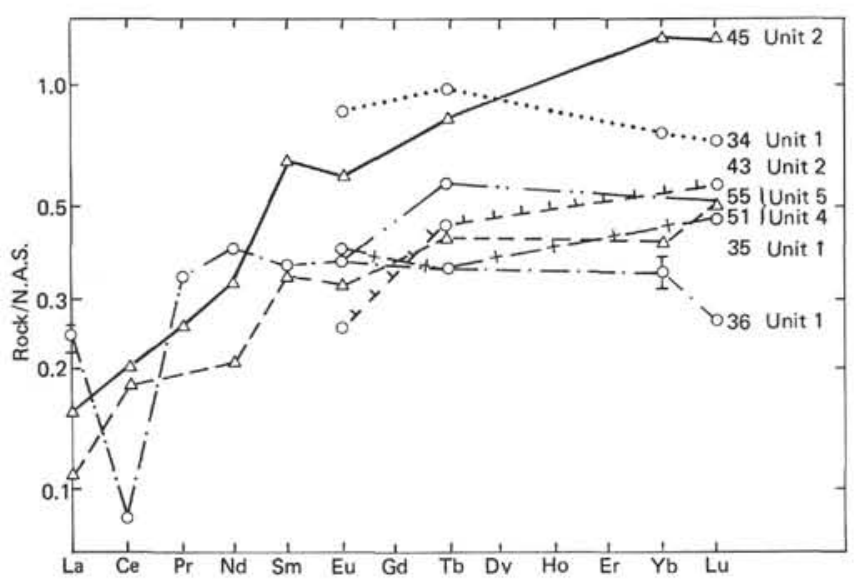

Figure 18. Shale-normalized REE distribution in the sediments and tuffs at Hole 448. (N.A.S. = North American shale; Units 1, 2, 4, and 5 refer to unit numbers used in the Site 448 report, this volume.)

glass reaches $75 \%$ volume. Samples (Table 11; Fig. 19) from this unit (Sample 6-Sample 449-8-3, 97-103 cm and Sample 8-Sample 449-10-4, 90-95 cm) are very similar in general chemistry to Sample 5 but show sharp differences in REE contents and distribution patterns. Sample 6 is characterized by higher lanthanide concentrations, a clear-cut cerium depletion, and an enrichment in heavy REE, whereas Sample 8 displays the minimal lanthanide concentrations and a progressive enrichment in heavy lanthanides, i.e., it has a REE range typical of the volcanic ashes in the region. The REE concentrations also are similar to those in ashes.

The lowest unit of the lower Miocene sediments in Hole 449 (Sample 10; Fig. 19) is represented by carbonate nannofossil ooze with admixtures of dispersed clay minerals. Iron and manganese micronodules are present. The REE concentrations, calculated on a carbonate-free basis, however, in this sample are the highest of all units of this hole.
The sediments forming the upper part of Hole 450 (the eastern side of the Parece Vela Basin) also show a variable REE distribution. Pliocene pelagic clays are marked by REE concentrations that are close to those of the North American shale average, although they exhibit a slight enrichment in heavy lanthanides relative to light ones (Sample 11-Sample 450-1-4, 144-150 cm). The underlying upper Miocene clays (Sample 12-Sample 450-5-2, 144-150 cm) contain about 50\% ash and are characterized by a REE abundance transitional between those in the overlying clays and the underlying volcanic tuffs (Fig. 20).

Hole 451 sediments, from the West Mariana Ridge remnant arc, are topped by a nannofossil-foraminiferous ooze-the only non-volcanic unit. The REE distribution patterns are characterized by a distinct enrichment in heavy lanthanides (Fig. 21). These distribution patterns are significantly different from those in Neogene-Quaternary sediments obtained from other holes drilled in the southern part of the Philippine Sea as well as from the REE distributions in upper Miocene tuffs underlying this unit. Dacites from Hole 448 (Samples 45 and 47) that display tholeiitic distribution patterns have the closest affinity. It is possible that the peculiarities of the REE in this unit may have resulted from the contribution of younger ash dacites, frequently encountered in Pliocene sediments (Karig, 1971).

Thus, in summary, the different REE distribution patterns in these sediments were probably not from a single source or the result of a single process. Judging from the REE distribution patterns, the sediments of the remnant island arcs (Sites 448, 451) might have at least two major REE sources. On the one hand, volcaniclastic material has dominated the REE distribution patterns in many units of the carbonate section of the holes (e.g., mainly the lower part of Hole 448). On the other hand, biogenic sedimentation of carbonates introduces the involvement of seawater in formation of the REE patterns (Spirn, 1965; Turekian et al., 1973; Piper, 1974). Under conditions of a decreased volcaniclastic influx, the seawater influence has lead to a distinct cerium depletion. This Ce anomaly is especially characteristic of the upper sediments of Hole 448.

Interpretation of these data on the sediments of the inter-arc basins has proven more complex. The upper sedimentary layers of these basins (the West Philippine Basin, Site 447, lower Miocene Samples 25 and 26; and the Parece Vela Basin, Site 449, upper Miocene through Quaternary Samples 1-4, and Site 450, Pleistocene Sample 11) were formed under conditions of normal pelagic sedimentation, an extremely low influx of ash, and very slow sedimentation rates. Many authigenic minerals (Piper, 1974) that resulted from the interaction of volcanic material and seawater show some characteristics of the REE patterns of seawater. Therefore we may assume that authigenic minerals have played an important role in the REE distribution in the youngest sediments from Hole 447A (Sample 26, Fig. 17). In turn, this has caused a cerium depletion and a relative enrichment in heavy lanthanides. Recent and Pliocene sediments of Hole 450 show a slight domination of ter- 
Table 11. INAA of rare-earth, trace, and major elements in Hole 449.

\begin{tabular}{|c|c|c|c|c|c|c|c|c|c|c|c|c|c|c|c|c|}
\hline Sample & $\begin{array}{l}\text { Core-Section } \\
\text { (interval in } \mathrm{cm} \text { ) }\end{array}$ & Rock & Age & $\mathrm{Ce}$ & Eu & $\mathrm{Tb}$ & $\mathrm{Yb}$ & Lu & Th & $\mathrm{Hf}$ & $\mathrm{Sc}$ & $\mathrm{Sb}$ & $\mathrm{SiO}_{2}$ & $\mathrm{Al}_{2} \mathrm{O}_{3}$ & $\mathrm{Fe}_{2} \mathrm{O}_{3}$ & $\mathrm{~K}_{2} \mathrm{O}$ \\
\hline N 1 & $\begin{array}{c}2-2 \\
140-150\end{array}$ & Pelagic clay & Pleistocene & 59 & 2.54 & 1.76 & 5.3 & 0.87 & 11.2 & 4.6 & 22.1 & 9.4 & 51.7 & 17.45 & $\frac{10.8}{10.6}$ & 2.55 \\
\hline $\mathrm{N} 2$ & $\begin{array}{c}4-3 \\
48-50\end{array}$ & Pelagic clay & $\begin{array}{l}\text { Late } \\
\text { Miocene? }^{\mathrm{a}}\end{array}$ & 41 & 1.49 & 1.52 & - & 0.51 & 2.9 & 2.2 & 21.6 & 1.1 & 54.6 & 15.45 & $\frac{10.0}{7.8}$ & 1.31 \\
\hline N 3 & $\begin{array}{c}3-3 \\
136-140\end{array}$ & Pelagic clay & Pliocene? $^{\mathrm{a}}$ & 69 & 3.61 & 2.23 & - & 1.04 & 8.9 & 4.2 & 24.3 & 7.6 & 51.0 & 17.9 & $\frac{10.7}{10.0}$ & 2.50 \\
\hline N 4 & $\begin{array}{c}5-1 \\
140-150\end{array}$ & Pelagic clay & $\begin{array}{l}\text { Late } \\
\text { Miocene? }\end{array}$ & 27 & 1.77 & 1.97 & - & 0.82 & 2.4 & 2.0 & 27.4 & 2.2 & 54.2 & 14.40 & $\frac{11.2}{10.1}$ & 1.19 \\
\hline N 5 & $\begin{array}{c}7-5 \\
24-29\end{array}$ & $\begin{array}{l}\text { Nannofossil } \\
\text { ooze }\end{array}$ & $\begin{array}{l}\text { Middle } \\
\text { Miocene }\end{array}$ & 17 & 1.26 & 1.08 & - & 0.66 & 1.5 & 1.2 & 12.7 & 0.88 & 30.0 & 6.80 & $\begin{array}{l}5.9 \\
-\end{array}$ & 0.62 \\
\hline N 6 & $\begin{array}{c}8-3 \\
97-103\end{array}$ & Pelagic clay & $\begin{array}{l}\text { Early } \\
\text { Miocene }\end{array}$ & 24 & 1.85 & 1.50 & - & 0.8 & 1.4 & 2.6 & 26.1 & 1.5 & 52.6 & 12.40 & $\frac{13.1}{12.7}$ & 1.45 \\
\hline N 8 & $\begin{array}{c}10-4 \\
90-95\end{array}$ & $\begin{array}{l}\text { Ash-bearing } \\
\text { pelagic clay }\end{array}$ & $\begin{array}{l}\text { Early } \\
\text { Miocene }\end{array}$ & 17 & 1.34 & 0.89 & 3.0 & 0.38 & 1.7 & 1.4 & 28.5 & - & 52.8 & 14.3 & $\frac{13.3}{11.2}$ & 2.27 \\
\hline N 10 & $\begin{array}{c}12-2 \\
102-104\end{array}$ & $\begin{array}{l}\text { Nannofossil } \\
\text { ooze }\end{array}$ & $\begin{array}{l}\text { Early } \\
\text { Miocene }\end{array}$ & 21 & 1.21 & 1.09 & 3.17 & 0.42 & 1.5 & 0.6 & 7.6 & 0.9 & 16.8 & 4.85 & $\frac{5.00}{5.00}$ & 0.77 \\
\hline
\end{tabular}

a These ages are an estimation by extrapolation, assuming constant accumulation rates.

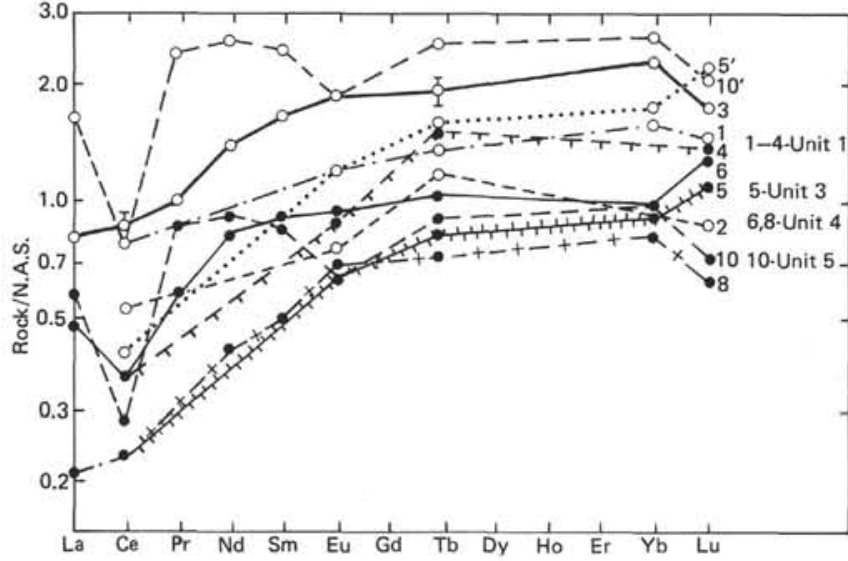

Figure 19. Shale-normalized REE distribution in the sediments at Hole 449. The sample numbers are represented by symbols, as indicated. N.A.S. = North American shale; Units 1, 3, 4, 5 refer to unit numbers used in the site report, this volume. Samples $5^{\prime}$ and $10^{\prime}$ show results on a carbonate-free basis.)

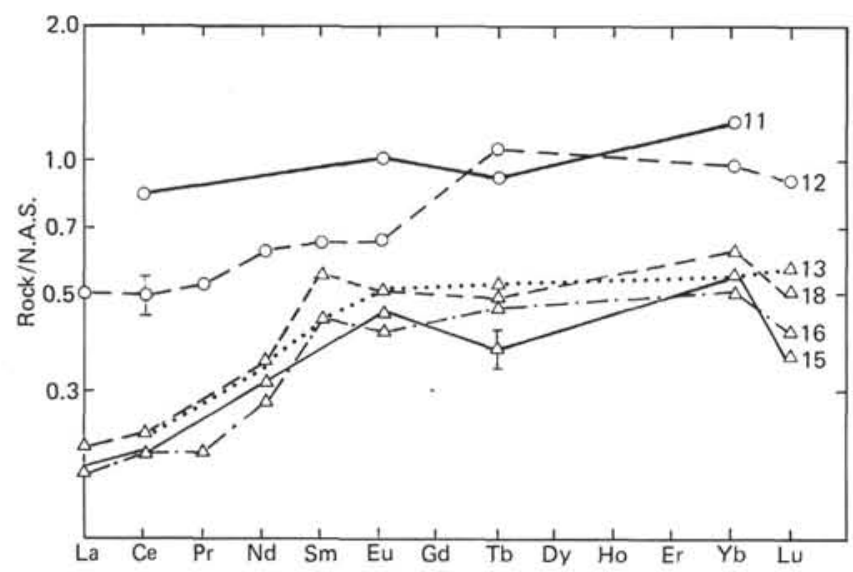

Figure 20. Shale-normalized REE distribution in the sediments and tuffs at Hole 450. (N.A.S. = North American shale. Sample numbers used in the text are indicated.)

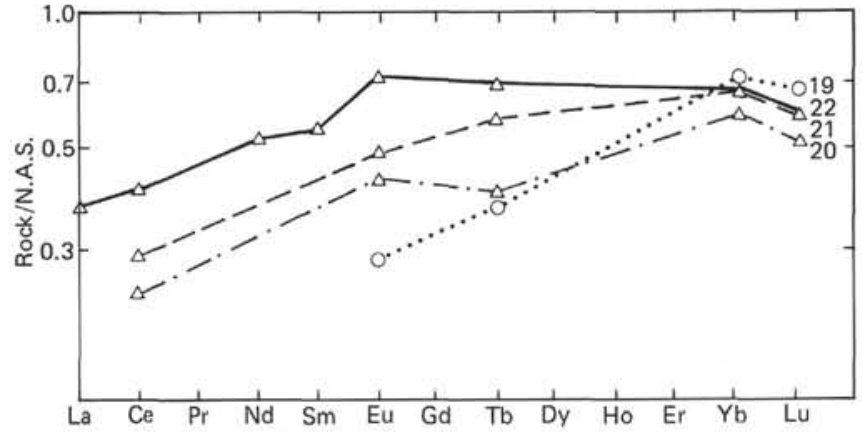

Figure 21. Shale-normalized REE distribution in the sediments and tuffs at Hole 451. (N.A.S. = North American shale. Sample numbers used in the text are indicated.)

rigenous material, which is displayed in a flat REE distribution curve, close to that of shales (Fig. 20). Neither seawater nor terrigenous material, however, affect the REE distributions in the upper clay unit at Hole 449. Despite the absence of volcaniclastics, the REE distribution corresponds to that in the volcanic rocks, although it is characterized by higher REE contents (Fig. 19). In this connection, it should be noted that the documented data on the REE distributions in minerals that originated from the interaction between seawater and volcanic rocks (montmorillonites, chlorites, zeolites etc., Copeland et al., 1971; Hellman and Henderson, 1977; Balashov, 1976) do not always reveal the features of the REE spectrum of seawater. In the majority of the cases, the authigenic minerals inherit lanthanide patterns from the source rock, and, in some cases, an increase in REE concentrations occurs without changing the characteristics of the REE spectrum. Possibly a Ce depletion or its excess in the products of halmyrolisis, as well as other characteristics of the lanthanide spectrum of seawater, depend on the time of contact between seawater and newly formed mineralogical phases. The effect of volcanic material on the REE distribution is 
especially pronounced in the lower sedimentary units of the inter-arc basins.

Considerable amounts of volcanic glass are identified in many layers of the units. Sample 8 (Sample 449-10-4, $90-95 \mathrm{~cm}$ ) contains about $30 \%$ of this material. Volcanic glass occurrences in clay material in Samples 28 and 30 are also possible (Sample 447A-5-5, 54-56 cm and Sample $447 \mathrm{~A}-7-4,80-82 \mathrm{~cm}$ ). In any case, it is evident that the REE distribution in these samples, analogous to that in the basalt-derived sedimentary breccia, results from the contribution of ashes or from transformation of the latter into clay minerals (Copeland et al, 1971). Also, another factor affecting REE distribution data is of interest: the role of hydrothermal fluids as contributor to formation of the lower sedimentary horizons of the inter-arc basins. This source usually occurs in the spreading zones, where active volcanism and seawater interaction brings about the formation of metalliferous deposits (Boström, 1973; Bender et al., 1971; Piper, 1973; Dymond et al., 1973; Bonatti, 1975; Bonatti, Honnorez-Guerstein et al., 1976; Cronan, 1976; Zelenov, 1964; Strakhov, 1976; Lisitsin et al., 1976; Migdisov et al., 1979).

Concentrations and distribution patterns of trace elements and REE in these formations vary widely, depending on the type and morphology of the depositional basin, the intensity of the hydrothermal influx, and the rate of terrigenous sedimentation (Migdisov et al., 1979). REE elements in terrigenous sediments are derived from seawater and the REE contribution from the hydrothermal material is actually insignificant. Available data indicate that where rapid accumulation of the metalliferous deposits occurs, the abundance of trace elements is low, except for $\mathrm{Zn}, \mathrm{Pb}$, and occasionally $\mathrm{Cu}$ and $\mathrm{Mo}$. The concentrations of the elements derived from seawater depend on the length of contact between seawater and the hydrothermal products (Bonatti et al., 1972; Migdisov et al., 1979).

In accordance with Karig's data (1971), the lower units of the sedimentary sections in the western part of the Parece Vela Basin contain the best examples of the basal sediments synchronous with the spreading that formed the Parece Vela Basin. Lower Miocene Site 449 sediments are identified within the same interval.

Evidently, the lower sediments of Hole 447A, and especially the variegated clay (Unit 4) overlying the sedimentary volcaniclastic breccia, have some appearances of the mottled clays from hydrothermally active zones (Lisitsin et al., 1976; Hekinian et al., 1978) and may contain evidence of the effect of the hydrothermal fluid on sedimentation.

All these units, both the younger (lower Miocene) and older (middle Oligocene), are characterized by a somewhat greater $\mathrm{Fe} / \mathrm{Al}$ ratio (up to 1.5 ), which can serve as an indicator of a possibility of additional $\mathrm{Fe}$ from an exhalation source. Bonatti, Honnorez-Guerstein, et al. (1976) have pointed out that four factors can indicate rapid accumulation of submarine hydrothermal metalliferous deposits. These are:

1) emplacement at the base of a sedimentary sequence just over the basaltic basement;
2) low ratios of minor elements relative to the sum of $\mathrm{Fe}$ and $\mathrm{Mn}$;

3) high U/Th ratios; and

4) a REE distribution marked by a Ce depletion.

The lower Miocene clays and carbonates of Hole 449 correspond in general to the above conditions. The rocks overlie basalts and have higher iron contents as well as considerably lower ratios of minor elements to the sum of $\mathrm{Fe}$ and $\mathrm{Mn}$ relative to the overlying pelagic clays (Fig. 22). Owing to this fact, the REE concentrations in iron hydroxides or in clay minerals resulting from this process in Sample 8 (Sample 449-10-4, 90-95 $\mathrm{cm}$ ) have proved insignificant relative to their abundance in volcanic glass and in clay minerals derived from it. The REE distribution in other samples from this sedimentary unit is marked by a clear-cut Ce depletion; the REE distribution also shows that the lanthanide distributions are very close to those in the sediments affected by hydrothermal processes. Thus the data on REE contents and distributions in the lower Miocene portion of the sedimentary sequence in the western part of the Parece Vela Basin do not contradict the assumption that the $\mathrm{Fe}$ input to the sediments has derived partially from hydrothermal solutions. The distribution of other trace elements is not contradictory to this conclusion. In accordance with the condition of a high U/Th ratio postulated by Bonatti, HonnorezGuerstein et al. (1976), low thorium concentrations are observed in this layer of sediments relative to the overlying units of the sequence (Table 10). The maximum $\mathrm{Zr} / \mathrm{Hf}$ ratios (Fig. 23) are observed in the sediments at the greatest concentrations of nonterrigenic $\mathrm{Fe}$ (which is not related to $\mathrm{Al}$ ). This phenomenon was also documented for the metalliferous depositions in the southeastern part of the Pacific Ocean (Migdisov et al., 1979, fig. 27).

At the same time, $\mathrm{Zr}, \mathrm{Hf}$, Th, Co, Ba, and Sc concentrations diminish down-hole. This does not rule out the possibility of contribution of hydrothermal fluid poor in minor elements to the lower portions of the sedimentary sequence (see Samples 6, 8, 10, Fig. 22). All the samples show a relationship between REE and phos-

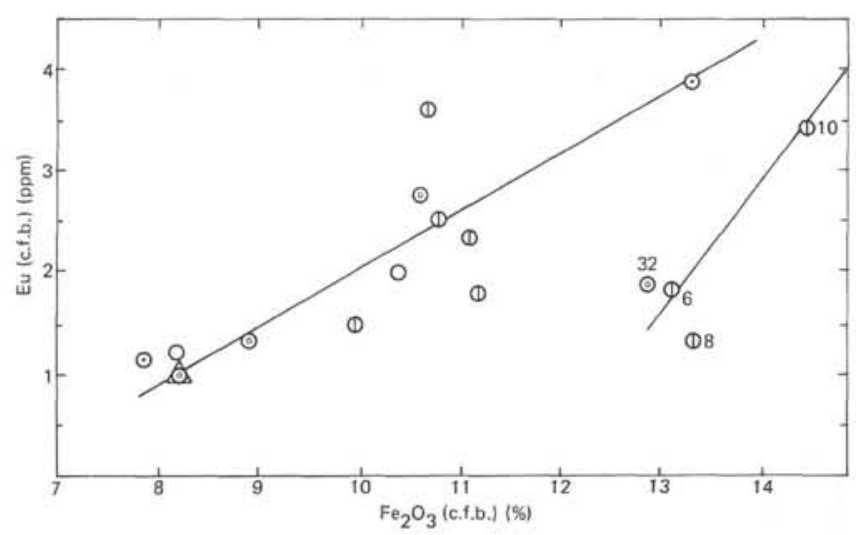

Figure 22. Eu content (calculated on a carbonate-free basis [c.f.b.]) relative to the ferric oxide content in the sediments at Holes $447 \mathrm{~A}$ through 451. (See Fig. 12 for symbol identification.) 


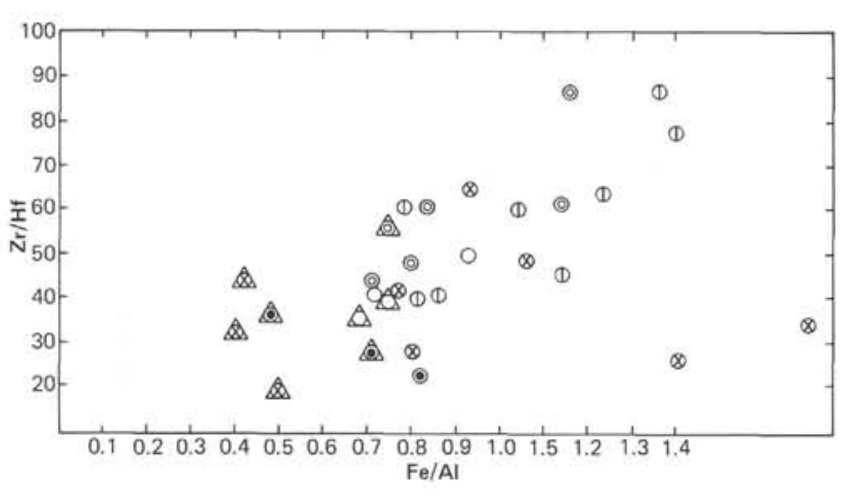

Figure 23. Correlation between $\mathrm{Zr} / \mathrm{Hf}$ and $\mathrm{Fe} / \mathrm{Al}$ in the sediments and tuffs at Holes 447A-451 (see Fig. 12 for symbol identification).

phorus (Fig. 24). The lower zone of the sediments at Hole 447A, and the layer of variegated clay (Unit 4) in particular (Sample 32), contrast with the above units and are not characterized by all features of the sediments containing some hydrothermal contributions. The REE distribution in these sediments does not differ significantly from that of the basalt-derived breccia. In general, the distribution patterns of the elements in Sample 32 are similar to those in tuffs. Although the distribution of other trace elements does not deny the possibility of an additional $\mathrm{Fe}$ input, the data do not discriminate between multiple origins of the REE patterns of the lower sedimentary units at Hole 447A.

\section{CONCLUSIONS}

An analysis of trace elements, and the REE among them, in the volcanic ashes and sediments of the southern part of the Philippine Sea penetrated by drilling during DSDP Leg 59 enables us to arrive at the following preliminary conclusions:

1) The REE distribution patterns and REE concentrations vary with the age of the tuffs and with the hole location in the Mariana island-arc system. The REE

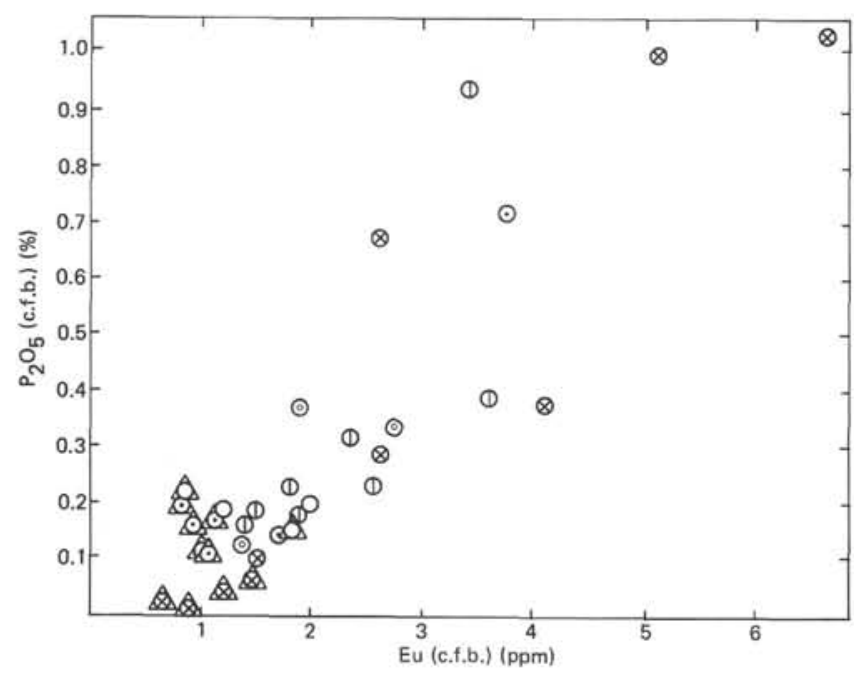

Figure 24. Correlation between Eu and $\mathrm{P}_{2} \mathrm{O}_{5}$ concentrations (calculated on a carbonate-free basis [c.f.b.]) in the sediments and tuffs at Holes 447A through 451. (The symbols used in Fig. 12 apply.) concentrations and a relative abundance of light lanthanides in volcaniclastic units increase from middle Oligocene (at Site 448) to upper Miocene ashes (at Site 451). The former are similar to tholeiitic island-arc associations; the latter are similar to calc-alkalic islandarc volcanic rocks.

2) A comparison between the REE distribution and the mineralogic composition of the tuffs suggests that many characteristics of the REE distribution in the volcaniclastic sediments might result from secondary processes (alteration of volcanic glass or clay mineral contribution during sedimentation) and not from the primary magmatic distribution.

3) The distribution of other trace elements in the tuffs is related to the petrochemical characteristics of the rocks.

4) The REE distribution patterns in carbonate sedimentary rocks and in sediments of the remnant island arcs (Sites 448 and 451) are marked by a considerable effect of volcaniclastic rocks. Biogenic pelagic carbonate sedimentation, which has REE distribution patterns typical of seawater, controls the REE pattern during decreases in volcanic activity (the upper sediments at Hole 448).

5) The pelagic clay sediments of the upper part of the inter-arc basin sequence (Holes 447A, 449, 450) appear to be characterized by different occurrences of terrigenous materials and authigenic minerals. In turn, this leads to REE variations, which range from the values close to those in shales to a Ce depletion and a heavy lanthanide enrichment.

6) The basal sediments of Hole 449 are marked by REE and other trace-element distributions that do not rule out a possibility of input from hydrothermal sources associated with spreading. The character of REE distributions in the variegated clay overlying the sedimentary volcaniclastic breccia at Hole $447 \mathrm{~A}$, however, does not appear to be of hydrothermal origin.

\section{REFERENCES}

Balashov, Y. A., 1976. Geokhimia Redkozemelnyh Elementov: Moscow (Nauka), p. 266.

Bender, M., Broecker, W., Gornitz, V., et al., 1971. Geochemistry of three cores from the East Pacific Rise. Earth Planet. Sci. Lett., $12: 425-433$.

Bonatti, E., 1975. Metallogenesis at oceanic spreading centers. Ann. Rev. Earth Planet. Sci., 3:401-431.

Bonatti, E., Fisher, D., Joensuu, O., et al., 1972. Iron-manganesebarium deposits from the Afar Rift (Ethiopia). Econ. Geol., 67: 717-730.

Bonatti, E., Honnorez-Guerstein, M. B., Honnorez, J., et al., 1976. Hydrothermal pyrite concretions from the Romanche Trench: metallogenesis in oceanic fracture zones. Earth Planet. Sci. Lett., $32: 1-10$.

Bonatti, E., Zerbi, M., Kay, R., et al., 1976. Metalliferous deposits from the Apennine ophiolites: Mesozoic equivalents of modern deposits from oceanic spreading centers. Bull. Geol. Soc. Am., 87:83-94.

Boström, K., 1973. The origin and fate of ferromanganoan active ridge sediments. Stockholm Contrib. Geol., 27:149-243.

Copeland, R. A., Frey, F. A., and Wones, D. R., 1971. Origin of clay minerals in a Mid-Atlantic Ridge sediment. Earth Planet. Sci. Lett., 2:186-192.

Cronan, D. S., 1976. Basal metalliferous sediments from the Eastern Pacific. Bull. Geol. Soc. Am., 87:928-934. 
Degens, E. T., and Ross, D. A. (Eds.), 1969. Hot Brines and Recent Heavy Metal Deposits in the Red Sea: New York (SpringerVerlag).

Dymond, J., Corliss, J., Heath, G., et al., 1973. Genesis of iron-rich sediments from the East Pacific Rise. Bull. Geol. Soc. Am., $84: 3355-3372$.

Ewart, A., and Bryan, W. B., 1972. Petrography and geochemistry of the igneous rock from Eua, Tongan Island. Bull. Geol. Soc. Am., 83:3281-3298.

Ewart, A., Bryan, W. B., and Gill, J. B., 1973. Mineralogy and geochemistry of the younger volcanic island of Tonga, S.W. Pacific. J. Petrol., 14 (Part 3):429-465.

Ewart, A., Taylor, S. R., and Capp, A. C., 1968. Trace and minor element geochemistry of the rhyolitic volcanic rocks of central North Island, New Zealand. Contrib. Mineral. Petrol., 18:76-104.

Flanagan, F. J., 1973. 1972 values for international geochemical reference samples. Geochim. Cosmochim. Acta, 37:1189-1200.

Gelman, E. M., Varshal, G. M., Bogdanova, V. I., et al., 1963. Primenenie hromatographicheskogo razdeljenia REE K analizu prirodnyh y promyshlennych materialov. In Riabchikov, D. I. (Ed.), Redkoziemelnye Elementy: Moscow (Nauka), p. 272.

Gill, J. B., 1973. Role of underthrust oceanic crust in the genesis of a Fijian calc-alkaline suite. Contrib. Mineral. Petrol., 43:23-45.

Haskin, L. A., Frey, F. A., Schmitt, R. A., et al., 1966. Meteoritic, Solar, and Terrestrial Rare-earth Distributions: New York (Pergamon Press).

Hekinian, R., Rosendahl, B., Cronan, D. S., et al., 1978. Hydrothermal deposits and associated basement rocks from the Galapagos spreading center. Oceanol. Acta, 1:473-482.

Hellman, P. L., and Henderson, P., 1977. Are rare earth elements mobile during spilitisation? Nature, 267:38-40.

Jakeš, P., and Gill, 1970. Rare earth elements and the island-arc tholeiitic series. Earth Planet. Sci. Lett., 9:17-18.

Jakeš, P., and Taylor, S. R., 1974. Excess europium content in precambrian sedimentary rocks and continental evolution. Geochim. Cosmochim. Acta, 38:739-745.

Karig, D. E., 1971. Structural history of the Mariana Island arc system. Bull. Geol. Soc. Am., 82:323-344.

Lisitsin, A. P., Bogdanov, Y. A., Murdmaa, I. O., et al., 1976. Metallonosnye osadki i ih genesis. Geologo-Geophisicheskie Issledovania Ugo-voskochnoi Chasti Tihogo Okeana: Moscow (Nauka).
Migdisov, A. A., Bogdanov, Y. A., Lisitsin, A. P., et al., 1979. Geohimia metallonosnyh osadkov. In Smirnov, Y. I. (Ed.), Metallonosnye Osadki Jugo-vostochnoi Chasti Tihogo Okeana: Moscow (Nauka), pp. 122-200.

Piper, D. Z., 1973. Origin of metalliferous sediments from the East Pacific Rise. Earth Planet. Sci. Lett., 19:75-82. , 1974. Rare earth elements in sedimentary cycle: a summary. Chem. Geol., 14:285-304.

Piper, D. Z., and Greaf, P. A., 1974. Gold and rare earth elements in sediments from the East Pacific Rise. Mar. Geol., 17:287-297.

Piper, D. Z., Veeh, H., Betrand, W., et al., 1975. An iron-rich deposit from the North-East Pacific. Earth Planet. Sci. Lett., 26:114-120.

Randle, K., 1974. Some trace element data and their interpretation for several new reference samples obtained by neutron activation analysis. Chem. Geol., 13:237-256.

Robertson, A., and Fleeta, A., 1976. The origin of rare earth in metalliferous sediments of the Troodos Massife, Cyprus. Earth Planet. Sci. Lett., 28:385-394.

Ronov, A. B., Balashov, Ju. A., Girin, Ju. P., et al., 1974. Regularities of rare-earth element distribution in the sedimentary shell and in the crust of the earth. Sedimentology, 21:171-193.

Ronov, A. B., Balashov, Ju. A., and Migdisov, A. A., 1967. Geochemistry of the rare earth elements in the sedimentary cycle. Geochem. Int., 4:1-17.

Spirn, R. V., 1965. Rare earth distribution in the marine environment [Ph.D. thesis]. Massachusetts Inst. of Tech., Cambridge, Mass.

Strakhov, N. M., 1976. Problemy Sovremennogo Okeanskogo Litogeneza: Moscow (Nauka).

Taylor, S., 1968. The geochemistry of andesites. In Ahrens, L. H. (Ed.), Origin and Distribution of the Elements: London (Pergamon Press).

Turekian, K. K., Katz, A., and Chan, L., 1973. Trace element trapping in pteropod tests. Limnol. Oceanogr., 18:240-249.

Varshal, G. M., and Riabchikov, D. I., 1964. Gravimetricheskoe opredelenie summy okislov RZE v porodah, mineralah i splavah. J. Anal. Chem. USSR, 19:202-207.

Zelenov, K. K., 1964. Gelezo i marganets v eksgaliatsiah podvodnogo vulcanisma Banu-Buhu (Indonesia). Dokl. Akad. Nauk. SSSR, 155:1317-1320. 